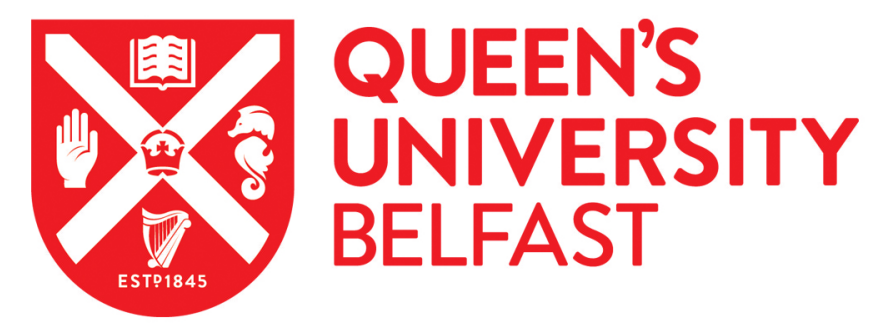

\title{
Magnitude, form and bioavailability of fluvial carbon exports from Irish organic soils under pasture
}

Barry, C. D., Renou-Wilson, F., Wilson, D., Müller, C., \& Foy, R. H. (2016). Magnitude, form and bioavailability of fluvial carbon exports from Irish organic soils under pasture. Aquatic Sciences, 78(3), 541-560.

https://doi.org/10.1007/s00027-015-0464-x

Published in:

Aquatic Sciences

Document Version:

Publisher's PDF, also known as Version of record

Queen's University Belfast - Research Portal:

Link to publication record in Queen's University Belfast Research Portal

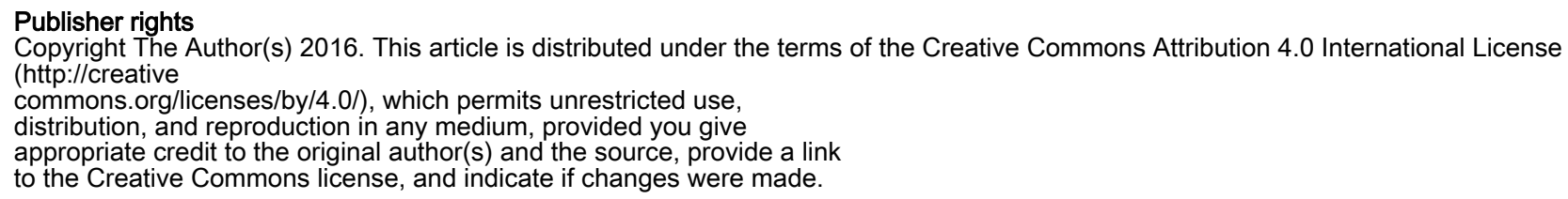

Copyright The Author(s) 2016. This article is distributed under the terms of the Creative Commons Attribution 4.0 International License (http://creative

commons.org/licenses/by/4.0/), which permits unrestricted use,

distribution, and reproduction in any medium, provided you give

appropriate credit to the original author(s) and the source, provide a link

to the Creative Commons license, and indicate if changes were made.

\section{General rights}

Copyright for the publications made accessible via the Queen's University Belfast Research Portal is retained by the author(s) and / or other copyright owners and it is a condition of accessing these publications that users recognise and abide by the legal requirements associated with these rights.

Take down policy

The Research Portal is Queen's institutional repository that provides access to Queen's research output. Every effort has been made to ensure that content in the Research Portal does not infringe any person's rights, or applicable UK laws. If you discover content in the Research Portal that you believe breaches copyright or violates any law, please contact openaccess@qub.ac.uk. 


\title{
Magnitude, form and bioavailability of fluvial carbon exports from Irish organic soils under pasture
}

\author{
C. D. Barry ${ }^{1,2}$ - F. Renou-Wilson ${ }^{3}$ D. Wilson ${ }^{4}$ C C. Müller ${ }^{5}$ R. H. Foy ${ }^{2}$
}

Received: 9 January 2015/Accepted: 29 December 2015

(C) The Author(s) 2016. This article is published with open access at Springerlink.com

\begin{abstract}
Organic soils are widespread in Ireland and vulnerable to degradation via drainage for agriculture. The soil-landuse combination of pasture on organic soils may play a disproportionate role in regional $\mathrm{C}$ dynamics but is yet to receive study. Fluvial $\mathrm{C}$ fluxes and labile organic fractions were determined for two such sites at nested field (c. 4 ha) and subcatchment scales ( $>40 \mathrm{ha}$ ); one relatively dry and nutrient rich, the other wetter and nutrient poor. Field scale flux from the nutrient poor site over 2 years was $38.9 \pm 6.6 \mathrm{~g} \mathrm{C} \mathrm{m}^{-2} \mathrm{yr}^{-1}$ with DIC $>$ DOC $>$ POC at 57,32 and $11 \%$ respectively, and $72 \%$ DIC was comprised of above equilibrium $\mathrm{CO}_{2}$. At the nutrient rich site, which overlies limestone geology, field scale export over an individual year was $90.4 \mathrm{~g} \mathrm{C} \mathrm{m}^{-2}$ with DIC $>$ DOC $>$ POC at 49,42 and $9 \%$, but with $90 \%$ DIC as bicarbonate. By comparison with the nutrient poor site, the magnitude and composition of inorganic $\mathrm{C}$ exports from the nutrient rich site implied considerable export of soil-respiratory $\mathrm{C}$ as bicarbonate, and lower evasion losses due to carbonate system
\end{abstract}

This article is part of the special issue 'CarbonCycling in Aquatic Ecosystems'.

\section{D. Barry}

chris.barry@afbini.gov.uk

1 Agri-Food and Biosciences Institute, Newforge Lane, Belfast BT9 5PX, Northern Ireland, UK

2 School of Biological Sciences, Queen's University Belfast, Belfast BT9 7BL, Northern Ireland, UK

3 School of Biology and Environmental Science, University College Dublin, Belfield, Dublin 4, Ireland

4 Earthy Matters Environmental Consultants, Glenvar, Letterkenny, Co., Donegal, Ireland

5 Institute for Plant Ecology, Justus Liebig University Giessen, Giessen, Germany buffering. Labile DOC determined using dark incubations indicated small fractions (5-10\%) available for remineralisation over typical downstream transit times of days to weeks. These fractions are probably conservative as photolysis in the environment can increase the proportion of labile compounds via photocleavage and directly remineralise organic matter. This study demonstrates that monitoring at soil-water interfaces can aid capture of total landscape fluvial fluxes by precluding the need to incorporate prior $\mathrm{C}$ evasion, although rapid runoff responses at field scales can necessitate high resolution flow proportional, and hydrograph sampling to constrain uncertainty of flux estimates.

Keywords DOC $\cdot \mathrm{DIC} \cdot \mathrm{CO}_{2} \cdot$ Fluvial flux $\cdot$ Carbon . Agriculture · Bioavailability $\cdot$ Reactivity continuum

\section{Introduction}

Fluvial exports of terrestrial carbon (C) have long been recognised as important modulators of aquatic ecosystem structure and function (Birge and Juday 1927; Prairie 2008). Consideration of their importance as components of terrestrial and global $\mathrm{C}$ budgets is more recent however (Billett et al. 2004; Cole et al. 2007), and partly reflects that climate change has prompted the need for more accurate greenhouse gas (GHG) inventories and raised interest in the C sequestration capacity of soils to offset anthropogenic emissions (Smith et al. 1997; IPCC 2006). The importance of, and requirement to include landscape-aquatic $\mathrm{C}$ transfers in studies of the global $\mathrm{C}$ system is underlined by comparable estimates for the global fluvial flux of terrestrial $\mathrm{C}$ and the terrestrial sink for anthropogenic $\mathrm{C}$ emissions (Cole et al. 2007; Canadell et al. 2007; Battin et al. 2009). 
Terrestrial organic $\mathrm{C}$ budgets are constructed as the balance of inputs and outputs. The largest respective terms are generally gross primary production (GPP) and direct aerobic respiration $(\mathrm{R})$ losses to the atmosphere, but these are insufficient alone to accurately determine the $\mathrm{C}$ status of sites. Dissolved organic C (DOC) in precipitation is an additional input, while net removal of matter by grazing organisms and/or as agricultural product, anaerobic respiration losses, and fluvial $\mathrm{C}$ exports are further loss terms. Fluvial $\mathrm{C}$ fluxes make the most appreciable contribution to terrestrial $\mathrm{C}$ balances in landscapes where organic soils predominate and where runoff is high. Undisturbed temperate and boreal peatlands are generally net atmospheric $\mathrm{C}$ sinks for $20-50 \mathrm{~g} \mathrm{C} \mathrm{m}^{-2} \mathrm{yr}^{-1}$, with fluvial fluxes equating to $34-46 \%$ of the sum of all other balance terms (Roulet et al. 2007; Nilsson et al. 2008; Dinsmore et al. 2010). Thus failure to incorporate fluvial losses can lead to appreciable overestimation of the terrestrial sink.

$\mathrm{C}$ is exported fluvially in several forms, distinguishable by size, elemental composition and molecular structure; foremost divisions are to organic and inorganic pools which are further apportioned to dissolved and particulate fractions. As carbonic acid is formed by dissolution of carbon dioxide $\left(\mathrm{CO}_{2}\right)$, which reacts with the bases of carbonate and silicate geology to yield alkalinity and establish the carbonate equilibria, fluvial exports of dissolved inorganic C (DIC) can comprise $\mathrm{C}$ derived from the atmosphere, respiration of soil organic matter, and rock weathering (Stumm and Morgan 1996; Telmer and Veizer 1999). Crucially, dissolution of carbonates and silicates yields bicarbonate in which respectively, half and all of the $\mathrm{C}$ present originates from carbon dioxide, which can have both atmospheric and organic matter respiratory origin (Stallard 1998; Telmer and Veizer 1999). As acidity donated from soil respiratory $\mathrm{CO}_{2}$ is often the dominant mechanism for dissolution, large portions of DIC can be derived from organic matter degradation, and failure to consider such fractions can bias terrestrial $\mathrm{C}$ balances (Cole et al. 2007; Rantakari and Kortelainen 2008; Kindler et al. 2011). Fluvial exports of organic $C$ are ultimately derived from photosynthetic fixation of atmospheric $\mathrm{CO}_{2}$, but due to variable donor vegetation, storage and diagenesis in soils prior to hydrologic export they consist of a multitude of compounds with varying age, elemental composition and biochemical reactivity (Marín-Spiotta et al. 2014).

A consequence of the diverse forms and biochemical characteristics of fluvial $\mathrm{C}$ exports is that numerous interrelated biological and physico-chemical processes modify their fate during downstream transport (Prairie 2008; Tranvik et al. 2009). Overall such processes contribute to losses of fluvial $\mathrm{C}$ downstream via burial in aquatic sediments and by gaseous evasion to the atmosphere, and globally these are of sufficient magnitude to influence the partitioning of $\mathrm{C}$ between the hydrosphere, geosphere and atmosphere (Stallard 1998; Aufdenkampe et al. 2011). Given that approaches to global $\mathrm{C}$ accounting tend to distinguish ocean and continental processes and their associated atmospheric mass fluxes, assessing the fate of fluvial C exports before delivery to the oceans is valuable. For example $\mathrm{CO}_{2}$ concentrations in most freshwaters exceed atmospheric such that water-air transport occurs, and such gradients are generated largely by organic matter remineralisation occurring pre and post export from soils and groundwater environments (Cole et al. 1994; Dawson et al. 2004; Fasching et al. 2014). Consequently knowledge of the quantities and rates of remineralisation of fluvial organic exports, largely determined by their biochemical reactivity and propensity for photolysis, can inform the potential return of $\mathrm{C}$ to the atmosphere. Indeed distinguishing allochthonous (soil) and autochthonous (aquatic) $\mathrm{CO}_{2}$ in freshwaters is crucial for understanding of the role of aquatic metabolism in the global $\mathrm{C}$ cycle (Maberly et al. 2013). Furthermore, as $\mathrm{CO}_{2}$ evasion is rapid in low order water courses due to high concentrations and often turbulent flows, tendencies for fluvial monitoring at spatial scales beyond soil-stream interfaces can underestimate landscape fluxes (Bishop et al. 2008; Wallin et al. 2013). Notably, improved knowledge of the areal extent of waterbodies and their gas transfer have approximately doubled estimates of the global evasion flux from freshwaters (Cole et al. 2007; Aufdenkampe et al. 2011; Raymond et al. 2013). Ireland possesses several characteristics conducive to high fluvial $\mathrm{C}$ loss rates and aquatic $\mathrm{C}$ processing. Soil organic carbon densities are high, carboniferous limestone geology is widespread, freshwater nutrients are elevated by agriculture, winters are mild, and freshwater density and connectivity are high, yet there are few studies of fluvial C exports or processing (EPA 2008; Koehler et al. 2010; Whitfield et al. 2011). Peat soils cover $17 \%$ of the land area in Ireland and represent $53 \%$ of the national soil C inventory (Tomlinson 2005). Pastures cover $53 \%$ and although only $6 \%$ are situated on peats, they account for $52 \%$ of the national organic $\mathrm{C}$ inventory to $50 \mathrm{~cm}$ (Xu et al. 2011). The combination of grasslands over peat in concert with artificial drainage may therefore play a disproportionate role in regional $\mathrm{C}$ dynamics but has yet to receive study. To address this gap and provide fluvial components for an allied terrestrial $\mathrm{C}$ balance study (Renou-Wilson et al. 2014) we determined organic and inorganic fluvial C fluxes at small spatial scales for two such sites. In addition we examine the potential for remineralisation of dissolved organic matter (DOM) exports and the associated timescales using high resolution biological oxygen demand measurements over 90 days. 


\section{Methods}

\section{Study sites}

Site A is in County Donegal $\left(55^{\circ} 9^{\prime} \mathrm{N}, 7^{\circ} 34^{\prime} \mathrm{W}\right)$ at $40 \mathrm{~m}$ elevation while Site B in County Longford $\left(55^{\circ} 9^{\prime} \mathrm{N}, 7^{\circ} 34^{\prime}\right.$ $\mathrm{W})$ is at $38 \mathrm{~m}$ elevation. Both sites experience mild winters but cool summers with similar mean annual, minimum and maximum temperatures; long term averages (LTA) are 9, -2 , and $18{ }^{\circ} \mathrm{C}$ respectively (Mills 2000). Annual precipitation totals are also similar as at Malin Head, located $26 \mathrm{~km}$ north-east of Site A, precipitation is $1076 \mathrm{~mm}$ while at Mount Dillon, $2 \mathrm{~km}$ north-east of Site B, it is $1047 \mathrm{~mm}$ (1981-2010; Met Éireann 2013). As a percentage of rainfall, potential evapo-transpiration (PET) at Site A is lower (32-36 vs. $44 \%$ ) than at Site B (Mills 2000). The LTA runoff, calculated as precipitation less PET, is $710 \mathrm{~mm} \mathrm{yr}^{-1}$ at Site A and $586 \mathrm{~mm} \mathrm{yr}^{-1}$ at Site B. The mean slopes at Sites A and B are 0.1 and $0.01 \mathrm{~m} \mathrm{~m}^{-1}$ respectively and each has been drained for $>60$ years. Soils are classed as terric and limnic histosols respectively and satisfy definitions of peat based on organic matter soil depth (FAO 1998). Site A overlies Precambrian schist and gneiss and soils are 17-23\% C, with C:N of 16-21. At Site $\mathrm{B}$ base geology is carboniferous limestone and the soils, which are $38 \% \mathrm{C}$ with $\mathrm{C}: \mathrm{N}$ of 17 , overlie a layer of marl. Soils are classified as nutrient poor and rich at Sites A and $B$ respectively and are managed as pasture for beef production with livestocking rates of 0.6 and 1.2 units $\mathrm{ha}^{-1}$ respectively.

\section{Fluvial C exports}

\section{Runoff measurement}

A field drain was instrumented with a $60^{\circ} \mathrm{v}$-notch angle weir at Site A. Water level, using a pressure transducer, and temperature behind the weir were recorded at $5 \mathrm{~min}$ intervals (Orpheus mini, OTT Germany) and stage height was converted to flow (Q) using established relationships (Grant and Dawson 1997). The field drainage area at Site A could not be reliably determined with available digital elevation models (DEM) and so was estimated as the annual drain discharge volume, divided by annual runoff for the study area, calculated as annual precipitation at Malin Head minusPET for the site calculated according to Thornwaite and Mather (1955). This drain discharged to a stream with a catchment area of 38 ha (NASA 60 m DEM) in which soils and land use were comparable to the field drain. At Site B, a field ditch was selected for monitoring but the flat topography meant that a weir installation would raise the site water table. Consequently a pressure transducer was installed where the sides and base of the ditch were constrained to rectangular flume. It was not possible to robustly calibrate flows against level for this instrumentation so that level was employed as a surrogate for flow in export computations. Annual runoff was estimated by the same approach as for Site A, employing precipitation data from Mt. Dillon (Met Éireann). This watercourse discharged to a stream with a catchment area of 870 ha (NASA $60 \mathrm{~m}$ DEM) but land use cover also encompassed areas of exploited peat.

To derive export rates at Site A the estimated mass fluxes (described below) are normalised against the estimated drain catchment area. The export rates are thereby sensitive to the precision of the estimated drain catchment area, and so the precision of the estimated runoff values used to compute these areas. At site B the export rates are also sensitive to the precision of the runoff estimate as the direct product of the runoff rate with flow-weighted mean C concentrations (see flux estimation below) gives the export rate. To examine the precision of the seasonality of flows and the computed runoff and so export rates for these sites they are compared against flow timeseries and annual runoff values determined for gauged rivers in each of the study site locations (EPA 2014). For Site A these are the Crana and Lackagh Rivers, respectively gauged $16 \mathrm{~km}$ east and $22 \mathrm{~km}$ west of the site with catchment areas of 37 and $125 \mathrm{~km}^{2}$. These catchments have high proportions of uplands compared to Site A, and while comparisons of seasonality are not precluded on this basis they cannot be used to verify the computed runoff value at this site (LTA precipitation for River Crana is $1668 \mathrm{~mm}$ and Lackagh is $1648 \mathrm{~mm}$ ). For Site B, the Inny and Cross Rivers are employed, gauged $15 \mathrm{~km}$ south east and $26 \mathrm{~km}$ south of the site with catchment areas of 1108 and $103 \mathrm{~km}^{2}$ respectively. In contrast to Site $\mathrm{A}$, the flat topography and relatively consistent soil and geology in the region surrounding Site B suggests that runoff for rivers gauged at this location will be consistent with runoff computed as precipitation minus evapotranspiration. Indeed annual runoff for the Cross river over the study period was $785 \mathrm{~mm} \mathrm{yr}^{-1}$, which is close the balance between precipitation and evapotranspiration of $790 \mathrm{~mm} \mathrm{yr}^{-1}$. Annual runoff for the Inny river B was lower at $682 \mathrm{~mm} \mathrm{yr}^{-1}$, however this river drains a much larger area $\left(1108 \mathrm{~km}^{2}\right)$ in which precipitation and PET may differ compared to the site, and further this river is used for drinking water abstraction and passes through Lough Derravaragh which lies $35 \mathrm{~km}$ east of the study site with an area of c. $7 \mathrm{~km}^{2}$. The agreement achieved between computed and measured runoff at Site B tends to support the accuracy and utility of the approach for computing runoff at Site A, however we also present a sensitivity 
analysis of the derived exports rates using $\pm 5 \%$ alterations to the computed runoff rates.

\section{Sampling and laboratory analyses}

Grab samples were taken from the field drains and steams at each site: fortnightly at Site A, and monthly at Site B with in situ measurements of $\mathrm{pH}$, conductivity and dissolved oxygen (Professional Plus series handheld meter, YSI USA). Sampling at Site A covered the 2012 and 2013 hydrological years, running from October to September (2011-12, 2012-13), but only the 2012 hydrological year was sampled at Site B. Samples for dissolved organic C (DOC) concentration were immediately filtered through precombusted glass fibre filters (Whatman GF/C, nominal pore size $1.2 \mu \mathrm{m}$ ) into precombusted, pre-rinsed $40 \mathrm{ml}$ borosilicate glass vials, preserved with phosphoric acid and stored refrigerated in the dark until analysis. Unfiltered samples were stored in the dark in $2 \mathrm{~L}$ polyethylene containers for laboratory determination of Particulate Organic $\mathrm{C}$ (POC) and alkalinity. DOC concentration was determined as non-purgeable organic carbon by combustion (Shimadzu TOC- $\mathrm{V}_{\mathrm{CPH}}$, Japan). Analysis of standards was reproducible to within $2 \%$ over $0-100 \mathrm{ppm}$. POC was determined in duplicate with means reported, by loss on ignition at $550{ }^{\circ} \mathrm{C}$ for material retained on glass fibre filters (Whatman GF/C). The $\mathrm{C}$ fraction of organic matter was taken as 0.468 (Dean 1974). POC was not determined for samples in 2013 and concentrations for this period were estimated as POC:DOC for 2012. The $1.2 \mu \mathrm{m}$ distinction between dissolved and particulate fractions is relatively large and was employed firstly as it allowed for filtration of larger sample volumes and so collection of greater quantities of particulate material which improved analytical precision, and secondly because it would allow some passage of small particulate-bacterial aggregates to retain the microbial communities of these sites, although a standardised inoculum was also included as described below. We did not systematically assess the impact of this relatively large filter pore size on the concentrations and so flux estimates of DOC and POC, and consequently it is unclear to what extent our results are comparable with studies employing a $0.7 \mu \mathrm{m}$ filtration threshold between DOC and POC. Crucially however our approach does not exclude any size fraction of the organic $\mathrm{C}$ export.

DIC concentration and speciation were computed according to Stumm and Morgan (1996) from $\mathrm{pH}$, conductivity, and temperature measured in situ, and alkalinity determined by Gran titration (Metrohm ${ }^{\circledR}$, MEP Instruments). Briefly, dissolution of carbon dioxide establishes the carbonate equilibria which are $\mathrm{pH}$ dependent, so that knowledge of the concentration (activity) of an individual carbonate species allows calculation of the concentration of each carbonate species using Henry's Law, the law of mass action, and the dissociation constants which are temperature and ionic strength dependent. Thus in an aqueous solution in which the only titratable bases are bicarbonate/carbonate, alkalinity is related to the total inorganic $\mathrm{C}$ concentration by $\mathrm{pH}$. In natural waters non-carbonate inorganic anions also contribute to alkalinity but generally these are present in negligible quantities relative to carbonates. However, in softer (low carbonate) humic waters organic anions can appreciably contribute to alkalinity such that total inorganic $\mathrm{C}$ determined from alkalinity can be overestimated (e.g. Cantrell et al. 1990). The potential contribution of organic anions to the sample alkalinities and the associated impacts on the computed DIC concentrations and fluxes for the study sites are explored in the discussion.

\section{Flux estimation}

Fluxes were calculated from flow-weighted mean concentrations (FWMC) employing mean hourly flows/levels at the time of sampling according to 'Method 5' of Walling and Webb (1985). This method is recommended where sampling frequency is low and where there is not a good or any discharge-concentration relationship, as was the case in this study (Littlewood 1992). $95 \%$ confidence limits for flux estimates were computed following Hope et al. (1997). Catchment scale fluxes at Site A employed mean hourly drain flows, while for Site B the mean daily flow record of the Cross river was employed.

Fluvial C fluxes are compared with the component fluxes of the terrestrial $\mathrm{C}$ balance of these sites (determined over the same measurement period) as given by RenouWilson et al. (2014).

\section{Labile organic $\mathbf{C}$ determination}

The Biological Oxygen Demand (BOD) of filtered samples (Whatman GF/C) was measured manometrically at $6 \mathrm{~h}$ intervals over 90 days in the dark at $20{ }^{\circ} \mathrm{C}$ (Oxitop ${ }^{\circledR}$, Xylem, USA). A detailed description of the method is given by Reuschenbach et al. (2003). Nitrification was inhibited by addition of allylthiourea and a manufacturer produced trace element and nutrient suite and microbial inoculum was added to each sample. As DOC mineralisation rates are determined in the dark at $20{ }^{\circ} \mathrm{C}$ with a nutrient excess they are indicative of the potential for remineralisation rather than being environmentally realistic. Two sample blanks of Milli- ${ }^{\circledR}$ water (Merck Millipore, Germany) were run simultaneously with samples and their BOD time series were subtracted from those of the samples. As respiratory quotients (RQs) are known to vary above and below parity, oxygen demand was converted to 
C equivalence using a pragmatic RQ of 1 (del Giorgio and Cole 1998; Berggren et al. 2012). The implications of this $\mathrm{RQ}$ on the derived biodegradation rates are explored in the discussion.

\section{Degradation kinetics}

Bacterial consumption of simple organic compounds generally follows a first-order exponential decay, where the rate of biodegradation is proportional to the substrate concentration that is described by Eq. 1 (Søndergaard and Middleboe 1995).

$\mathrm{BOD}_{t}=\mathrm{BOD}_{t o t}\left(1-\exp ^{-k t}\right)$

where $\mathrm{BOD}_{t o t}$ is the total $\mathrm{BOD}, t$ is time and $k$ is the rate constant $\left(\mathrm{d}^{-1}\right)$.

Equation 1 can be reformulated for DOC with a residual term $\left(\mathrm{DOC}_{\mathrm{r}}\right)$ which is refractory and remains unchanged over time, and $\mathrm{DOC}_{\mathrm{L}}$ is the labile $\mathrm{C}$ concentration (Eq. 2).

$\mathrm{DOC}_{t}=\mathrm{DOC}_{L}\left(\exp ^{-k t}\right)+\mathrm{DOC}_{\mathrm{r}}$

If however the $\mathrm{DOC}_{\mathrm{L}}$ consists of a range of compounds with differing reactivity the time dependence of DOC requires information on the reactivity distribution of the organic matter present. This has been achieved by integration of first-order exponential decay functions over the reactivity distribution, assuming a continuous reactivity distribution of compounds (Aris 1989). The reactivity continuum of rate constants $(k)$ in Eqs. 1 and 2 can be formulated using the infinite- $k$ range gamma distribution, in which the exponential and power parts relate to labile and more refractory fractions respectively (Boudreau and Ruddick 1991). By this approach the proportions of the initial $\mathrm{C}$ concentration over time (t) can be expressed as:

$\frac{\mathrm{C}_{\mathrm{t}}}{\mathrm{C}_{\mathrm{o}}}=\left(\frac{\alpha}{\alpha+t}\right)^{v}$

Where $\alpha$ is a rate parameter relating to the lifespan of more labile compounds (days), and $v$ relates to the shape of distribution as $k \rightarrow 0$, such that $v$ describes the prevalence of refractory compounds; where $v$ is equal to 1 all compounds are equally reactive. The apparent initial first-order decay coefficient, $k$, by the gamma distribution is $v / \alpha$ $\left(\right.$ day $\left.^{-1}\right)$ with $v /(\alpha+t)$ describing the behaviour of $k$ over time (Boudreau and Ruddick 1991).

Equations 2 and 3 differ in their assumptions of the proportion of $\mathrm{OC}$ matter that is reactive. Here we employ both models as the derivation of a labile proportion by Eq. 2 has clear utility, while Eq. 3 provides a framework for comparing the reactivity composition of organic matter pools between samples. Model parameters for Eqs. 2 and 3 were derived using lme4 package version 1.1-7 in $R$ (Bates et al. 2013; R Core Development Team 2012).

\section{Results}

\section{Hydrology}

Precipitation was 17 and $10 \%$ greater than the long term average (LTA) at Sites A and B respectively in 2012 so that predicted runoff values, calculated as precipitation less PET, were above the LTA by $26 \%$ at Site A and $35 \%$ at Site B (Table 1). For the 2013 hydrologic year at Site A precipitation was close to the LTA $(<3 \%)$ so that runoff was only $5 \%$ above the LTA. The annual distributions of rainfall and runoff were similar at each site (Figs. 1a and 2a). Flows for the Site A drain were significantly correlated with the regional rivers at the $0.1 \%$ level. Figure 1a shows that drain was particularly flashy with a $\mathrm{Q}_{5}: \mathrm{Q}_{95}$ of 90 .

As the drainage area of the Site A drain in each year was estimated as the annual gauged discharge volume divided by annual runoff estimated as precipitation minus PET, the disparity in precipitation, PET, and discharge volumes between the 2 years yielded catchment areas that differed by $\mathrm{c} .1$ ha (Table 1$)$. The conventional approach whereby flow routing using DEMs defines the total potential area from which runoff may be generated (catchment area) does not account for variable source hydrology and its impact on estimated solute export rates, which can be appreciably altered depending on the scale and area unit considered (e.g. Thompson et al. 2012). Our approach normalises fluxes against the area from which runoff was estimated to be generated in each year and thus reduces the impact of variable runoff between years on export rates.

At Site B mean daily stage height was significantly correlated with mean daily runoff for the regional rivers at the $5 \%$ level. Runoff for the 2012 hydrologic year at this site was estimated at $790 \mathrm{~mm}$, close to that of the Inny River $(785 \mathrm{~mm})$. This agreement may reflect more consistent precipitation and PET across this area which is relatively flat, and indeed mean runoff for this river is close to that estimated as LTA precipitation minus PT for the area $\left(573\right.$ vs. $\left.586 \mathrm{~mm} \mathrm{yr}^{-1}\right)$.

\section{C concentrations and flux}

\section{Site A- non-calcareous}

Samples were acquired over a range of flows including several storm events and on rising and falling limbs of event hydrographs, but there were no significant annual or seasonal relationships between double log regressions of concentration vs. flow suggesting that 'method 5' was appropriate for calculating fluxes (Fig. 1a). Drain and catchment DOC concentrations were similar and correlated at the $1 \%$ level in both years (Fig. 1c, e). In 2013 both 
Table 1 Summary of hydrology and water chemistry for the 2012 and 2013 hydrologic years at the study sites

\begin{tabular}{|c|c|c|c|}
\hline & \multicolumn{2}{|l|}{ Site A } & \multirow{2}{*}{$\begin{array}{l}\text { Site B } \\
2012\end{array}$} \\
\hline & 2012 & 2013 & \\
\hline Discharge $\left(10^{-3} \mathrm{~m}^{3}\right)$ & 35.7 & 21.4 & $n d$ \\
\hline Precipitation (mm) & 1254 & 1105 & 1154 \\
\hline pT \% & 0.28 & 0.33 & 0.32 \\
\hline $\mathrm{pT}(\mathrm{mm})$ & 357 & 360 & 364 \\
\hline Runoff (mm) & 897 & 745 & 790 \\
\hline Catchment area (ha) & 3.98 & 2.87 & nd \\
\hline \multicolumn{4}{|l|}{ Drain samples (mean \pm se) } \\
\hline $\mathrm{pH}$ & $5.98 \pm 0.4$ & $5.81 \pm 0.06$ & $7.22 \pm 0.12$ \\
\hline Specific conductance $\left(\mu \mathrm{S} \mathrm{cm}{ }^{-1}\right)$ & $175 \pm 3$ & $154 \pm 4$ & $412 \pm 39$ \\
\hline Alkalinity (meq $\mathrm{l}^{-1}$ ) & $0.73 \pm 0.03$ & $0.71 \pm 0.03$ & $4.02 \pm 0.39$ \\
\hline $\mathrm{pCO}_{2}$ ( $\left.\mu \mathrm{atm}.\right)$ & $40,148 \pm 4676$ & $56,509 \pm 9155$ & $12,371 \pm 2628$ \\
\hline \multicolumn{4}{|l|}{ Catchment samples (mean \pm se) } \\
\hline $\mathrm{pH}$ & $6.98 \pm 0.07$ & $6.85 \pm 0.09$ & $7.58 \pm 0.08$ \\
\hline Specific conductance $\left(\mu \mathrm{S} \mathrm{cm}{ }^{-1}\right)$ & $193 \pm 8$ & $180 \pm 11$ & $495 \pm 27$ \\
\hline Alkalinity (meq $1^{-1}$ ) & $0.80 \pm 0.06$ & $0.83 \pm 0.07$ & $4.54 \pm 0.29$ \\
\hline $\mathrm{pCO}_{2}(\mu \mathrm{atm})$. & $4165 \pm 763$ & $6376 \pm 971$ & $5292 \pm 2628$ \\
\hline
\end{tabular}

$n d$ not determined drain and catchment DOC concentrations were significantly lower than in $2012(\mathrm{t}=4.08, \mathrm{p}<0.001$ and $\mathrm{t}=3.5, \mathrm{p}<0.01$ respectively). DIC concentrations were greater for the drain compared to the catchment due to higher $\mathrm{CO}_{2}$ concentrations so that DIC was a greater fraction of the total $\mathrm{C}$ in drain samples (50-80\%) compared to catchment samples (20-50\%) (Figs. 1b, d and 3). Higher $\mathrm{CO}_{2}$ concentrations were recorded for the drain in 2013 compared to $2012(\mathrm{t}=2.12, \mathrm{p}<0.05)$. The $p \mathrm{CO}_{2}$ in samples from the drain were 12-177 times atmospheric in 2012, and 42-320 times atmospheric in 2013, but lower for stream samples at 2-23 and 3-37 times atmospheric respectively. Alkalinity at Site A ranged from 0.3 to 1.0 meq $\mathrm{l}^{-1}$. Drain POC concentrations in 2012 ranged from 0.12 to $77 \mathrm{mg} \mathrm{l}^{-1}$ with median of $4.04 \mathrm{mg}^{-1}$ but there were no relationships with flow. Catchment POC concentrations tended to be less than those from the drain (median $2.6 \mathrm{mg} \mathrm{l}^{-1}$ ) while the maximum concentrations did not coincide with those from the drain (Fig. 1c, d).

The total C flux from the drain was greater than for the stream principally due to the much larger export of $\mathrm{CO}_{2}$ (Table 2). The drain flux of total C was $29 \%$ lower in 2013 compared to 2012, predominantly reflecting lower DOC export (Table 2). The stream export in 2013 behaved similarly with the total flux $45 \%$ lower in 2013 due to $67 \%$ lower DOC flux while the other constituent fluxes were within $1 \mathrm{~g} \mathrm{C} \mathrm{m}^{-2} \mathrm{yr}^{-1}$ of those in 2012. As previously discussed, the precision of the runoff estimate influences the precision of the derived export rates at Site A via its impact on the computed drain catchment area; a $5 \%$ discrepancy in the runoff rate alters the DOC and DIC export in 2012 by 0.95 and $1.0 \mathrm{~g} \mathrm{C} \mathrm{m}^{-2} \mathrm{yr}^{-1}$ respectively, and by 0.3 and $1.0 \mathrm{~g} \mathrm{C} \mathrm{m}^{-2} \mathrm{yr}^{-1}$ respectively in 2013 .

\section{Site B-calcareous}

There were no apparent relationships between sample C concentrations and stage height or river flows, and drain and catchment DOC concentrations were relatively consistent during periods of both high and low flow (Fig. 2c, d). In contrast to Site A where drain DIC was dominated by $\mathrm{CO}_{2}$, at Site B DIC was predominantly as $\mathrm{HCO}_{3}{ }^{-}$at both scales. This was despite high levels of $\mathrm{CO}_{2}$ supersaturation; the average $p \mathrm{CO}_{2}$ values for the drain and catchment samples were 32 (6-71) and 14 (5-24) times atmospheric respectively. $\mathrm{CO}_{2}$ accounted for $<10 \%$ of total sample $\mathrm{C}$ concentrations (Figs. 2 and 3). POC concentrations ranged from 0.4 to $7.6 \mathrm{mg} \mathrm{l}^{-1}$ for the catchment but were greater for the drain at 0.7 to $22.9 \mathrm{mg} \mathrm{l}^{-1}$ however this disparity may partly reflect disturbance by cattle watering upstream of the drain. Alkalinity ranged from 2.89 to 9.24 meq $1^{-1}$.

As with Site A, the precision of the computed runoff rate influences the accuracy of the $\mathrm{C}$ export rates for Site $\mathrm{B}$; here a $5 \%$ discrepancy in the computed runoff rate alters the DOC and DIC export rates for the drain in 2012 by 1.9 and $2.2 \mathrm{~g} \mathrm{C} \mathrm{m}^{-2} \mathrm{yr}^{-1}$ respectively. 
Fig. 1 Timeseries of hydrology (a) and inorganic $\mathrm{C}$ and organic $\mathrm{C}$ concentrations for the field drain (panels $\mathbf{b}, \mathbf{c}$ ) and wider catchment (panels $\mathbf{d}, \mathbf{e}$ ) at Site A covering the 2012 and 2013 hydrologic years

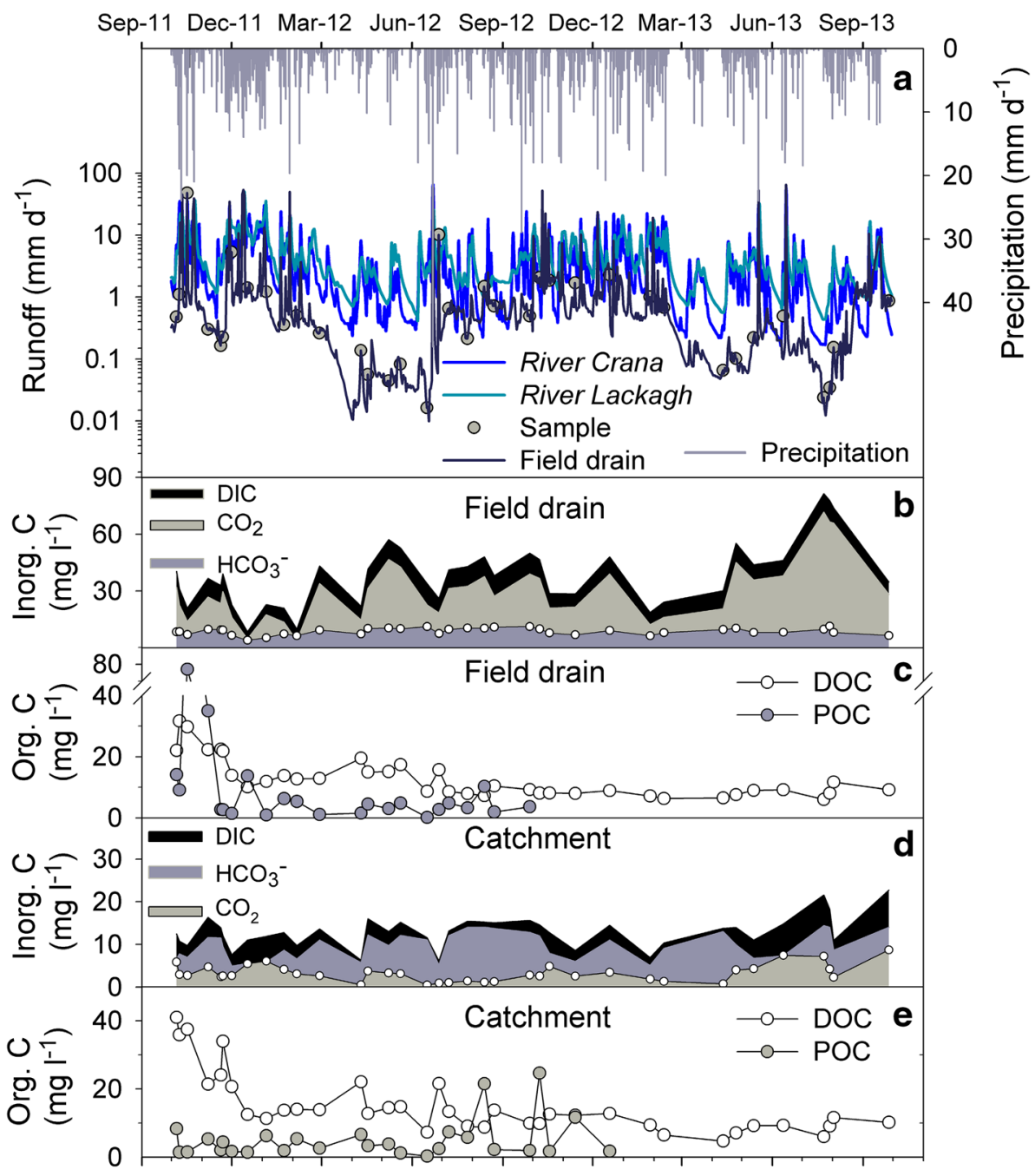

Sep-11 Dec-11 Mar-12 Jun-12 Sep-12 Dec-12 Mar-13 Jun-13 Sep-13

\section{Estimates of $C$ flux derived from landscape organic carbon}

Not all of the fluxes listed in Table 2 originate from terrestrial organic matter. Firstly allowance is made for precipitation inputs of DOC, calculated as the product of precipitation and a rainfall DOC concentration of $0.75 \pm 0.2 \mathrm{mg} \mathrm{l}^{-1}(\mathrm{n}=2)$ consistent with Willey et al. (2000), which give inputs of 0.67 and $0.56 \mathrm{~g} \mathrm{C} \mathrm{m}^{-2} \mathrm{yr}^{-1}$ for Site A in 2012 and 2013 respectively, and $0.59 \mathrm{~g} \mathrm{C} \mathrm{m}^{-2}$ $\mathrm{yr}^{-1}$ for Site B in 2013. Inorganic C inputs from precipitation, which largely reflect dissolution of atmospheric $\mathrm{CO}_{2}$, are also small; sample equilibrium $\mathrm{CO}_{2}$ concentrations ranged from 0.2 to $0.3 \mathrm{mg} \mathrm{l}^{-1}$ and fluxes computed by 'method 5' ranged from 0.16 to $0.23 \mathrm{~g} \mathrm{C} \mathrm{m}^{-2} \mathrm{yr}^{-1}$. Secondly the DIC flux at Site B is corrected for the contribution of geologic $\mathrm{C}$ inputs derived from dissolution of carbonate limestone geology, where, assuming half of the alkalinity derives from geological carbonate, the total $\mathrm{C}$ exports from the drain and stream are lowered by 20.1 and
$17.3 \mathrm{~g} \mathrm{C} \mathrm{m}^{-2} \mathrm{yr}^{-1}$. Together these modifications for rainfall $\mathrm{C}$ inputs and geologically derived $\mathrm{C}$ lower the total flux from the drain at Site B by $23 \%$ to $69.5 \mathrm{~g} \mathrm{C} \mathrm{m}^{-2} \mathrm{yr}^{-1}$ and the catchment flux by $29 \%$ to $43.4 \mathrm{~g} \mathrm{C} \mathrm{m}^{-2} \mathrm{yr}^{-1}$. The combined effects of these corrections to the flux at Site A are much smaller due to the absence of a geologically derived DIC component; the drain fluxes were lowered by only $2 \%$ in 2012 and 2013 to 44.5 and $31.6 \mathrm{~g} \mathrm{C} \mathrm{m}^{-2} \mathrm{yr}^{-1}$ respectively, and the catchment fluxes by $2.6 \%$ in 2012 and $3.7 \%$ in 2013 to 33.6 and $18.4 \mathrm{~g} \mathrm{C} \mathrm{m}^{-2} \mathrm{yr}^{-1}$ respectively.

When these adjustments are made the net drain fluxes of DIC estimated as derived from soil respiration at Sites A and $\mathrm{B}$ are nearly equal at c. $23 \mathrm{~g} \mathrm{C} \mathrm{m}^{-2} \mathrm{yr}^{-1}$. However the same adjustments to the catchment scale DIC fluxes give a flux from Site B approximately double that from Site A. This divergence at the larger spatial scale reflects the substantially lower $\mathrm{CO}_{2}$ flux at the catchment scale from Site A (lower by $11 \mathrm{~g} \mathrm{C} \mathrm{m}^{-2} \mathrm{yr}^{-1}$ ) compared to Site B 
Fig. 2 Timeseries of hydrology (a), inorganic and organic $\mathrm{C}$ concentrations for the field drain $(\mathbf{b}, \mathbf{c})$ and wider catchment $(\mathbf{d}$, e) at Site B covering the 2012 hydrologic year

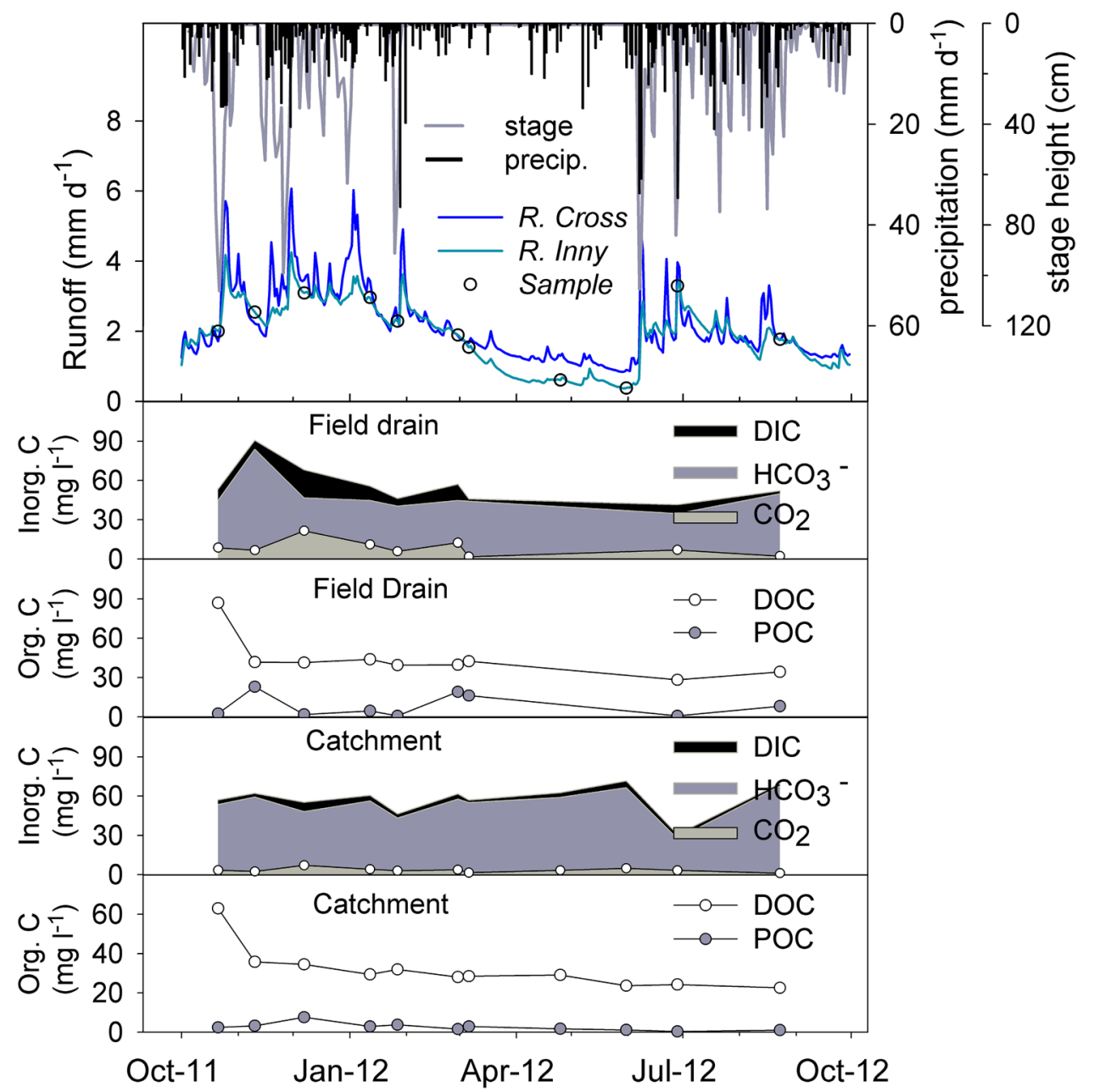

- Site A field drain

- Site A catchment

$\triangle \quad$ Site B field drain

$\triangle \quad$ Site B catchment

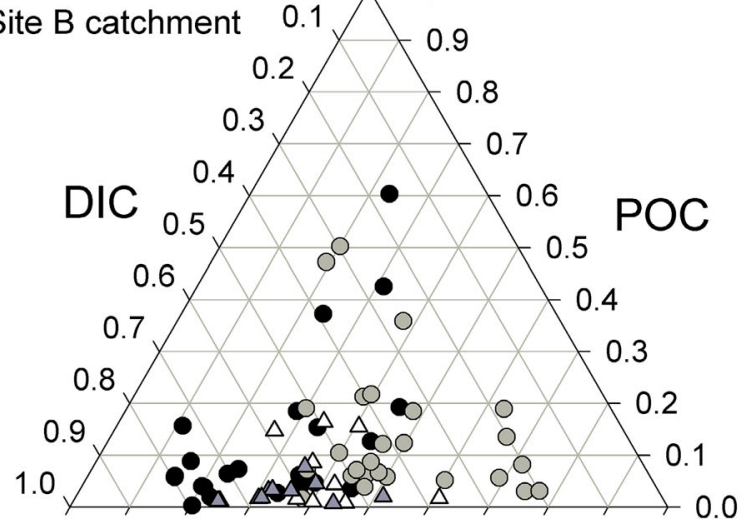

$\begin{array}{lllllllllll}0.0 & 0.1 & 0.2 & 0.3 & 0.4 & 0.5 & 0.6 & 0.7 & 0.8 & 0.9 & 1.0\end{array}$ DOC

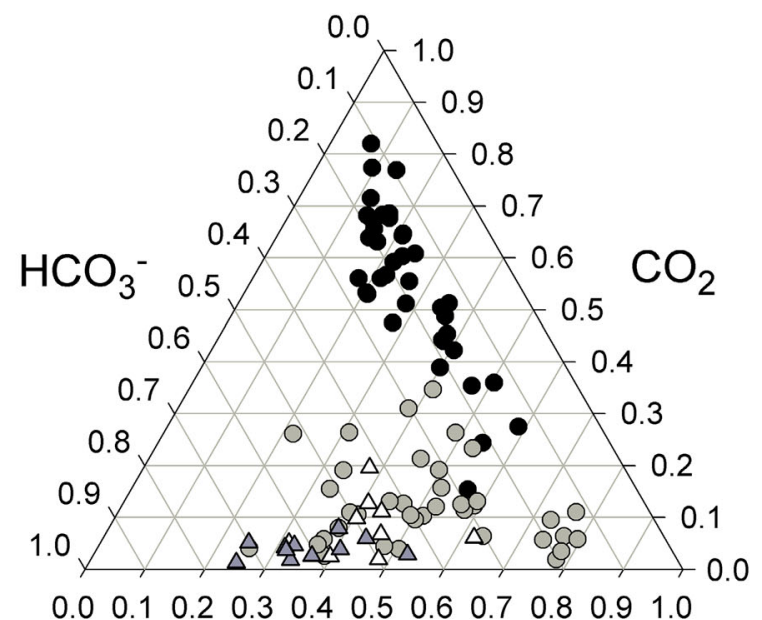

DOC

Fig. 3 Ternary plots for sample DOC, POC and DIC concentration (left) and DOC, $\mathrm{CO}_{2}$ and $\mathrm{HCO}_{3}{ }^{-}$concentration (right) 
Table 2 Summary of fluvial C fluxes $\left(F ; \mathrm{g} \mathrm{C} \mathrm{m}^{-2} \mathrm{yr}^{-1}\right), 95 \%$ Confidence Intervals $(C I)$, and flux as percent total (\%)

\begin{tabular}{|c|c|c|c|c|c|c|c|c|c|c|c|c|c|c|c|c|c|c|}
\hline & \multicolumn{3}{|c|}{ Site A drain 2012} & \multicolumn{3}{|c|}{ Site A drain 2013} & \multicolumn{3}{|c|}{ Site A catchment 2012} & \multicolumn{3}{|c|}{ Site A catchment 2013} & \multicolumn{3}{|c|}{ Site B drain 2012} & \multicolumn{3}{|c|}{ Site B catchment 2012} \\
\hline & $F$ & $C I$ & $\%$ & $F$ & $C I$ & $\%$ & $F$ & $C I$ & $\%$ & $F$ & $C I$ & $\%$ & $F$ & $C I$ & $\%$ & $F$ & $C I$ & $\%$ \\
\hline DOC & 19.0 & 13.2 & 42 & 6.0 & 1.1 & 19 & 24.1 & 2.8 & 70 & 8.0 & 2.5 & 42 & 37.7 & 20.7 & 42 & 22.2 & 10.3 & 36 \\
\hline POC & 6.4 & 11.2 & 14 & 2.0 & 0.4 & 6 & 1.8 & 9.7 & 5 & 1.7 & 0.5 & 9 & 7.9 & 8.6 & 9 & 2.0 & 2.1 & 3 \\
\hline DIC & 20.0 & 15.3 & 44 & 24.4 & 13.9 & 76 & 8.6 & 6.4 & 25 & 9.5 & 5.5 & 50 & 44.7 & 33.6 & 49 & 37.3 & 11.2 & 61 \\
\hline $\mathrm{CO}_{2}$ & 13.6 & 13.2 & 30 & 18.6 & 12.9 & 58 & 2.4 & 3.2 & 7 & 3.0 & 2.8 & 16 & 4.4 & 4.3 & 5 & 2.5 & 1.6 & 4 \\
\hline $\mathrm{HCO}_{3}$ & 6.4 & 1.5 & 14 & 5.8 & 0.3 & 18 & 6.2 & 5.7 & 18 & 6.5 & 3.6 & 34 & 40.2 & 33.8 & 44 & 34.7 & 11.4 & 56 \\
\hline Total & 45.4 & & & 32.3 & & & 34.5 & & & 19.1 & & & 90.4 & & & 61.5 & & \\
\hline
\end{tabular}

$F * 10=\mathrm{kg} \mathrm{ha}^{-1} \mathrm{yr}^{-1}$

(lower by $<2 \mathrm{~g} \mathrm{C} \mathrm{m}^{-2} \mathrm{yr}^{-1}$ ) which is indicative of lower $\mathrm{CO}_{2}$ evasion losses at Site $\mathrm{B}$ due to the more highly buffered carbonate system at this site which allows a large fraction of the export of soil respiratory $\mathrm{CO}_{2}$ to masquerade as bicarbonate export.

\section{DOC biodegradation}

\section{Exponential model (Eq. 2)}

The quantities of labile $\mathrm{C}\left(\mathrm{DOC}_{\mathrm{L}}\right)$ were similar between sites, but expressed as proportions of total DOC the labile fractions were lower for samples from Site B, where mineralisation expressed as $k$ in Eq. 2 occurred more slowly albeit at more consistent rates (Table 3). Labile DOC of samples from Site A ranged from 0.6 to $2.7 \mathrm{mg} \mathrm{C}$ $1^{-1}$, equivalent to 6-20\% initial DOC. The comparable values for Site $B$ were in the range $1.0-8.7 \mathrm{mg} \mathrm{l}^{-1}$ equivalent to 4-17\% of initial DOC. The highest value of $8.7 \mathrm{mg}^{-1}$ from Site B (sample b3) may be an outlier due to manures entering the drain at a cattle watering access point upstream of the sampling point. At both Sites there were no consistent differences in DOC mineralisation between samples from the drain and catchment scales. Rate constants $(k)$ ranged relatively widely with higher values indicative of more rapid consumption of a more reactive pool with rapid transition to lower consumption rates associated with more refractory $\mathrm{C}$, while lower values indicated more consistent consumption rates and lower heterogeneity of the reactivity of the labile $\mathrm{C}$. Rate constants did not exceed $0.25 \mathrm{~d}^{-1}$ and $k$ was lower on average for Site B $\left(0.27 \pm 0.17 \mathrm{~d}^{-1}\right.$ vs. $\left.0.11 \pm 0.03 \mathrm{~d}^{-1}\right)$ indicating that the labile $\mathrm{C}$ content was consumed less rapidly compared to samples from Site A.

\section{Reactivity continuum model (Eq. 3)}

Compared to the exponential model the reactivity continuum model provided a superior fit to the data in all cases; residual standard errors were factors of 10-60 lower compared to the exponential models, and Akaike Information Criterion weights averaged $-1059 \pm 217$ compared to $-252 \pm 70$ indicating stronger statistical performance (Table 3; Fig. 4a, b). Initial reactivities $(k)$ for samples from Site A were generally $>0.01 \mathrm{~d}^{-1}$, whereas, with the exception of sample b3, samples from Site B exhibited initial reactivities $<0.01 \mathrm{~d}^{-1}$ indicating that samples from Site A generally contained some matter with greater lability (Table 3; Fig. 4e, f). As with the exponential model, rate constants declined more slowly for samples from Site B (Fig. 4e, f). Indeed values for $\alpha$, which indicate the mean life time of the more reactive components, averaged $2.1 \pm 1.0$ days at Site A compared to $3.1 \pm 0.9$ days at Site B (Table 3). Values for $v$ were low at both sites indicating a large preponderance of refractory matter. Means were $0.034 \pm 0.008$ and $0.023 \pm 0.004$ for Sites A and B respectively. Beyond day 10, reactivities began to converge so that by day 50 rates were within $0.003 \mathrm{~d}^{-1}$ of each other despite having initially differed by $0.2 \mathrm{~d}^{-1}$ (Fig. 4e, f).

The probability distributions plotted in Fig. 4 are analogous to the proportion of initial DOC liable to degrade at rates below the respective rate value at curve intersection. These indicate that DOC with reactivity $>0.1 \mathrm{~d}^{-1}$ accounted for $1-10 \%$ of the initial DOC in samples from Site A, but only 1-2\% of initial DOC for samples from Site B (excepting sample b3). Similarly DOC with a reactivity $>0.001 \mathrm{~d}^{-1}$ accounted on average for 18 and $12 \%$ of the initial DOC for Sites A and B respectively, corresponding to the bulk of the degradation observed during the incubation period. The large preponderance of refractory DOC (low $v$ values) is consistent with the low fraction of labile $\mathrm{C}$ determined by the exponential model. The probability distributions indicate that $70-80 \%$ of DOC would degrade at low rates $<0.0001 \mathrm{~d}^{-1}$.

\section{Implications for DOC export}

The relatively low sample numbers limit capacity for examining the role of season or flow on DOC 


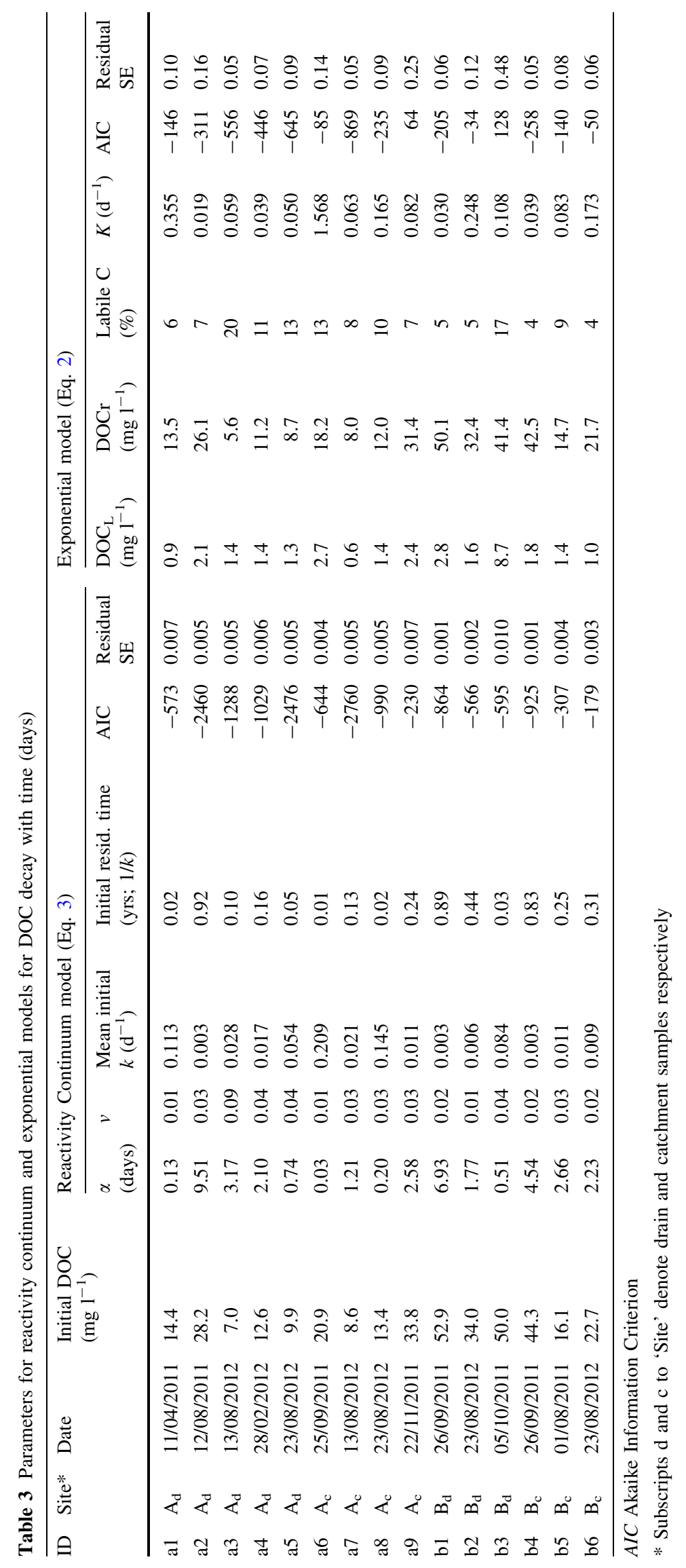



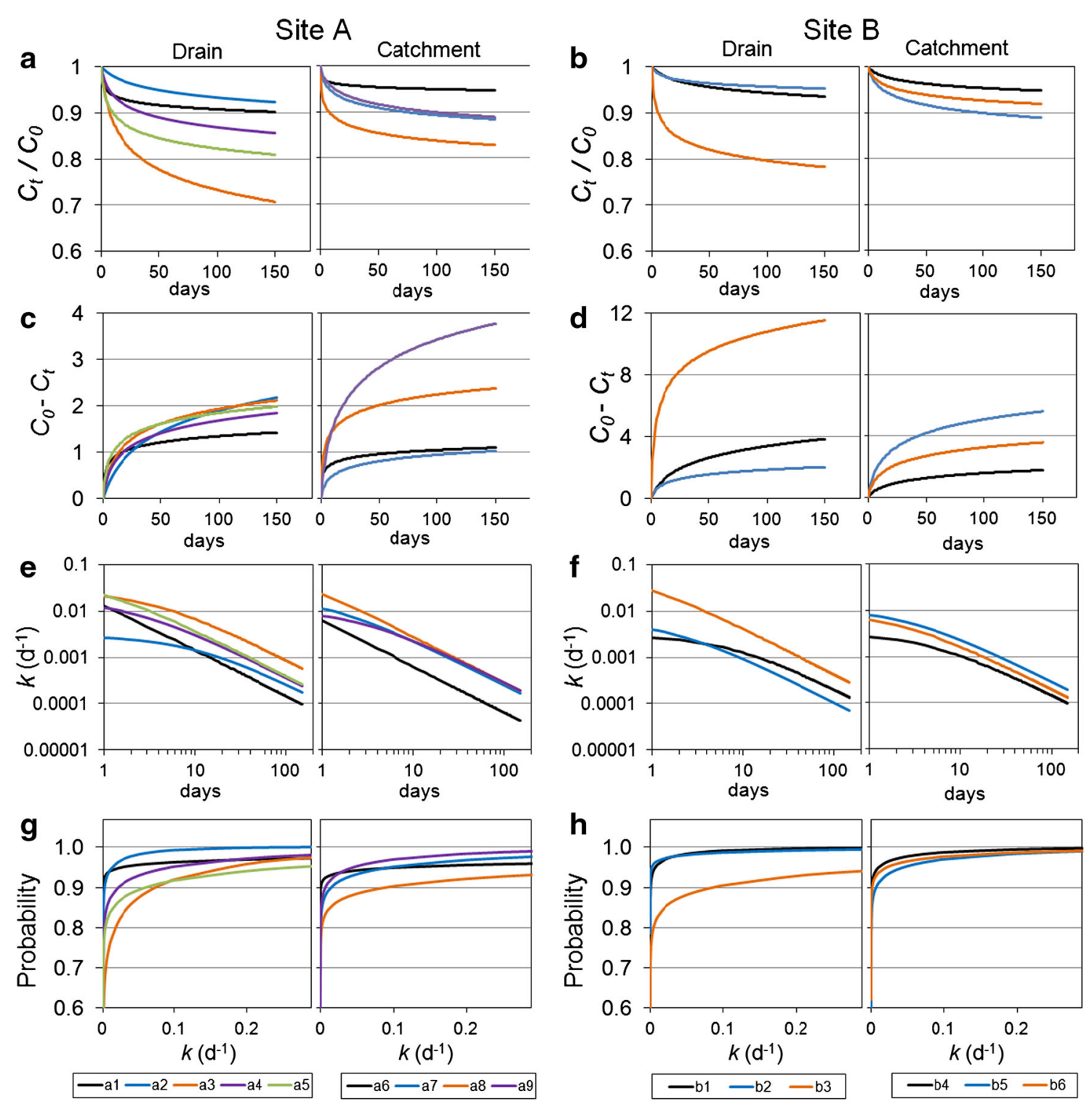

Fig. 4 Reactivity continuum model fits to experimental data. a, b timeseries of DOC as proportion of initial DOC $\left(\mathrm{C}_{t} / \mathrm{C}_{0} ; \%\right)$; $\mathbf{c}$, d timeseries of DOC remineralised $\left(\mathrm{C}_{0}-\mathrm{C}_{\mathrm{t}} ; \mathrm{mg}^{-1}\right)$; e, f: timeseries of mean first-order decay coefficients $(k) ; \mathbf{g}, \mathbf{h}$ : initial gamma reactivity

bioavailability, and no clear relationships with such parameters were found. Consequently the mean mineralisation time course of DOC exported from the sites was estimated from a reactivity continuum model employing the mean values of $\alpha$ and $v$ derived from all samples at each site. Sample b3 was excluded from this computation due to possible contamination with organic manure. For Site A this approach $(\alpha, v=2.19,0.028)$ predicts DOC degradation as follows: $5 \%$ at 10 days, $7 \%$ at 1 month, $10 \%$ at 3 months, $13 \%$ at 1 year, and $17 \%$ at 5 years. For Site B $(\alpha, v=3.63,0.020)$ the comparable values were $3 \%$ at 10 days, $4 \%$ at 1 month, $6 \%$ at 3 months, $9 \%$ at 1 year, and $12 \%$ at 5 years. Applying the percent DOC loss at

distributions. Curve identifications in legends refer to models and parameters given in Table 3 (note data extrapolated to 150 days for a-f)

1 year to the DOC flux estimates in Table 2 indicates remineralisation for Site A DOC exports equivalent to 2.5 and $0.8 \mathrm{~g} \mathrm{C} \mathrm{m}^{-2} \mathrm{yr}^{-1}$ in 2012 and 2013 respectively for the Drain, and 3.1 and $1.0 \mathrm{~g} \mathrm{C} \mathrm{m}^{-2} \mathrm{yr}^{-1}$ respectively for the catchment, and for Site B in 2012, $3.4 \mathrm{~g} \mathrm{C} \mathrm{m}^{-2} \mathrm{yr}^{-1}$ for the Drain and $2.0 \mathrm{~g} \mathrm{C} \mathrm{m}^{-2} \mathrm{yr}^{-1}$ for the catchment.

\section{Discussion}

Pasture on peat in Ireland covers an area of approximately $2400 \mathrm{~km}^{2}$ that accounts for $3 \%$ of the land area. Peatlands and organic soils altered by drainage to promote agriculture 
are recognised as GHG emission hotspots within the EU, and consequently knowledge of their contemporary status aids accurate assessment of national and regional GHG inventories, while informing on the capacity for emission reduction with mitigation (Joosten et al. 2012; RenouWilson et al. 2014).

\section{Magnitude and form of fluvial $\mathrm{C}$ exports}

Hope et al. (1994) reviewed DOC and DIC fluxes in the range $1-10 \mathrm{~g} \mathrm{~m}^{-2} \mathrm{yr}^{-1}$ for temperate and boreal zones but noted a paucity of information for $\mathrm{CO}_{2}$ and particulate $\mathrm{C}$ fluxes. Subsequently it has been found that the upper range of DOC fluxes from organic rich catchments is c. $20-40 \mathrm{~g} \mathrm{~m}^{-2} \mathrm{yr}^{-1}$ and that DIC, particularly as $\mathrm{CO}_{2}$, can be equivalent to an appreciable portion of net terrestrial gaseous C exchange (Hope et al. 2001; Dawson and Smith 2007; Rowson et al. 2010; Butman and Raymond 2011; Wallin et al. 2013 and references therein). POC has received renewed attention but estimates remain relatively poorly constrained due to predominant export during transient hydrological events, which was also the case here (Table 2; Cannell et al. 1999). At our sites POC fluxes were in the range $0.8-12 \mathrm{~g} \mathrm{C} \mathrm{m}^{-2} \mathrm{yr}^{-1}$. The U.K. POC fluxes summarised by Dawson and Smith (2007), largely for $\mathrm{C}$ rich uplands, are typically $0.5-2.0 \mathrm{~g} \mathrm{C} \mathrm{m}^{-2} \mathrm{yr}^{-1}$ but fluxes up to $31.7 \mathrm{~g} \mathrm{C} \mathrm{m}^{-2} \mathrm{yr}^{-1}$ have also been reported. While our catchment scale fluxes were generally c. $2 \mathrm{~g} \mathrm{C}$ $\mathrm{m}^{-2} \mathrm{yr}^{-1}$, the drain fluxes were greater but more uncertain with estimates of 6-7 $\pm 5 \mathrm{~g} \mathrm{C} \mathrm{m}^{-2} \mathrm{yr}^{-1}$.

Monitoring of DOC and DIC fluxes at various distances beyond soil-water interfaces has necessitated summation of fluvial fluxes with estimates of prior mineralisation and evasion to arrive at actual landscape losses (e.g. Öquist et al. 2009; Dinsmore et al. 2010). Few previous studies have determined field scale $\mathrm{C}$ fluxes where the need to account for prior DOC mineralisation and $\mathrm{C}$ evasion is largely precluded (Gibson et al. 2009; Rowson et al. 2010). The DOC losses of $12-48 \mathrm{~g} \mathrm{C} \mathrm{m}^{-2} \mathrm{yr}^{-1}$ in this study are consistent with those reported for $\mathrm{C}$ rich temperate and boreal catchments, particularly for areas receiving higher precipitation $\left(>1 \mathrm{~m} \mathrm{yr}^{-1}\right)$. Indeed Royer and David (2005) detail DOC fluxes of only $0.3-2.3 \mathrm{~g} \mathrm{C} \mathrm{m}^{-2} \mathrm{yr}^{-1}$ for tiledrained, row-cropped agricultural catchments situated on $\mathrm{C}$ rich mollisols in Illinois USA where annual runoff seldom exceeds $<500 \mathrm{~mm} \mathrm{yr}^{-1}$. The drain $\mathrm{CO}_{2}$ export rates for Site A (13.6-18.6 $\mathrm{g} \mathrm{C} \mathrm{m}^{-2} \mathrm{yr}^{-1}$ ) exceed reported DIC fluxes, but are consistent with reported $\mathrm{CO}_{2}$ evasion rates of 1.6-14.1 $\mathrm{g} \mathrm{C} \mathrm{m}^{-2}$ catchment $\mathrm{yr}^{-1}$ (Hope et al. 2001; Wallin et al. 2013 and references therein). Rowson et al. (2010) determined similar DOC and $\mathrm{CO}_{2}$ fluxes (29.4-85.8 and 14.7-20.9 $\mathrm{g} \mathrm{C} \mathrm{m}^{-2} \mathrm{yr}^{-1}$ respectively) to this study for field scale monitoring ( 0.75 and 0.24 ha) within a disturbed peatland in the U.K.. Our field scale fluxes are also close to estimates of biogenic DIC export of $8-24 \mathrm{~g} \mathrm{C} \mathrm{m}^{-2} \mathrm{yr}^{-1}$ determined from soil pore water concentrations combined with leaching estimates, however these were from well drained, more productive and lower $\mathrm{C}$ content soils in drier regions of Europe (Kindler et al. 2011).

The disparity between DIC flux estimates for the field and catchment scales at Site A, and to a lesser extent at Site $\mathrm{B}$, are consistent with catchment scale alterations of fluvial $\mathrm{CO}_{2}$ flux by evasion loss (Dawson et al. 2004). Although the characteristics of the field and catchment scales are unlikely to have been identical, at Site A where drainage water was relatively soft, the difference between the two probably reflects prior $\mathrm{CO}_{2}$ evasion from the catchment stream. On this basis, a rudimentary estimate of the mean $\mathrm{CO}_{2}$ evasion rate for the catchment stream above the sampling point at Site A can be made as the product of the balance between the drain and catchment $\mathrm{CO}_{2}$ exports (11.2 and $15.6 \mathrm{~g} \mathrm{C} \mathrm{m}^{-2} \mathrm{yr}^{-1}$ for 2012 and 2013 respectively; Table 2) and the catchment area (38 ha). From orthophotography the stream surface area above the sampling point is approximately $800 \mathrm{~m}^{2}$ indicating mean annual evasion rates of 243 and $338 \mathrm{mg} \mathrm{C} \mathrm{m}^{-2} \mathrm{~d}^{-1}$ for 2012 and 2013 respectively; these are within the range reported for headwaters draining organic soils (64-477 mg $\mathrm{C} \mathrm{m}^{-2} \mathrm{~d}^{-1}$; Hope et al. 2001; Billett et al. 2004).

The contribution of dissolved organic matter to the acidity and buffering capacity of freshwaters has been appreciated for several decades, particularly with respect to surface water acidification (Perdue and Gjessing 1990). More recently the utility of Gran alkalinity for the computation of DIC (and $\mathrm{pCO}_{2}$ ), as employed herein, has been questioned due to potential for overestimation due to contributions from non-carbonate sources of alkalinity, notably organic anions in humic waters (e.g. Hunt et al. 2011). Organic anion contributions to Gran alkalinity in humic lakes and streams have been determined in the range 1.6-2.0 $\mu \mathrm{eq} \mathrm{mg}{ }^{-1}$ DOC (Hedin et al. 1990; Kortelainen 1993; Roila et al. 1994). If such values are appropriate for the organic matter exported from our sites, then the assumption of $1.75 \mu \mathrm{eq}$ organic alkalinity $\mathrm{mg}^{-1}$ DOC would mean organic anion contributions to the total alkalinity of samples taken from the drain at site A in 2012 and 2013 of $1.5-9.0 \%$ (median $1.9 \%$ ) and 1.3-2.5 \% (median $2.2 \%)$ respectively. The organic contribution to the alkalinity of drain samples at Site B was 1.4-4.1\% (median $1.9 \%$ ). These contributions do not alter the annual flux estimates of DIC and $\mathrm{CO}_{2}$ flux beyond the $95 \%$ confidence intervals reported in Table 2; at Site A the drain DIC fluxes in 2012 and 2013 were 20.0 and $24.5 \mathrm{~g} \mathrm{C} \mathrm{m}^{-2} \mathrm{yr}^{-1}$, and $\mathrm{CO}_{2}$ fluxes were 13.6 and $18.7 \mathrm{~g} \mathrm{C} \mathrm{m}^{-2} \mathrm{yr}^{-1}$ respectively, but with the corrected alkalinity values these fluxes are reduced to 18.4 and $23.9 \mathrm{~g} \mathrm{C} \mathrm{m}^{-2} \mathrm{yr}^{-1}$ and 12.6 and $18.3 \mathrm{~g}$ 
$\mathrm{C} \mathrm{m}^{-2} \mathrm{yr}^{-1}$ respectively $\left(<1.6 \mathrm{~g} \mathrm{C} \mathrm{m}^{-2} \mathrm{yr}^{-1}\right)$. Similarly for the Site B drain the 2012 DIC and $\mathrm{CO}_{2}$ fluxes were 44.7 and $4.4 \mathrm{~g} \mathrm{C} \mathrm{m}^{-2} \mathrm{yr}^{-1}$, but these were reduced to 43.8 and $4.3 \mathrm{~g} \mathrm{C} \mathrm{m}^{-2} \mathrm{yr}^{-1}$ using corrected alkalinities. Thus fluxes computed using alkalinities corrected as above were within $1.6 \mathrm{~g} \mathrm{C} \mathrm{m}^{-2} \mathrm{yr}^{-1}$ at both sites.

Soil $\mathrm{C}$ and soil C:N typically explain high amounts of variability in DOC exports between catchments and, as argued by Aitkenhead-Peterson et al. (2005), such relationships probably represent aggregate measures of controls on DOC production and export by climatic, edaphic, biological and topographic catchment characteristics. Soil C:N at Sites A and B (17-21) are low but not markedly different, but as DOC export from Site B was approximately twice that of Site A the implication is that the nearly double soil C content at Site B compared to A was the principal driver. Drier conditions at Site B, on the basis of much greater PET, also imply a greater propensity for DOC production by virtue of more aerobic soil conditions. Although the field scale $\mathrm{CO}_{2}$ export from Site $\mathrm{B}$ was lower than Site A by c. $10 \mathrm{~g} \mathrm{C} \mathrm{m}^{-2} \mathrm{yr}^{-1}$, this difference is reversed when $50 \%$ bicarbonate export is attributed to soil respiration at Site B which implies greater soil respiration there. Indeed respiration appreciably exceeded Gross Primary Production (GPP) at Site B, but was similar to GPP at Site A (Fig. 5; Renou-Wilson et al. 2014).

Catchment and field scale $\mathrm{CO}_{2}$ fluxes at Site B were not as dramatically different as at Site A, and the bicarbonate exports at each scale were also similar at Site B. The implication is that biogenic DIC fluxes in situations of homogenous carboniferous geology behave conservatively due to bicarbonate buffering, so constraining evasion fluxes. As weathering losses of atmospheric $\mathrm{C}$ are balanced by returns of volcanic $\mathrm{CO}_{2}$ at million year timescales, and by ocean carbonate precipitation at millennial timescales, increased weathering rates combined with low inorganic $\mathrm{C}$ evasion losses will result in increased ocean storage (Beaulieu et al. 2012).

\section{Inter-annual variability at Site A}

In 2013 annual field and catchment scale DOC fluxes from Site A were approximately three times lower than in 2012 when precipitation was $17 \%$ above the LTA (Table 2). Notably peak DOC concentrations were observed at both drain and catchment scales at the start of the 2012 hydrologic year in October and November 2011 but comparable peaks were not observed at the start of the 2013 hydrologic year although flows were similar for samples in each of these years (Fig. 1). Pronounced intra-annual seasonality of DOC export has been determined for several Scottish catchments with temperature and hydrology identified as the principal drivers, and notably with catchments with annual drying and wetting regimes characterised by autumnal DOC export peaks (Dawson et al. 2008). The absence of such a relation in our dataset may reflect the unusual hydrology over a relatively short measurement period, or potentially also the bias toward sampling at lower flows. Seasonal peaks of DOC export are a characteristic of many headwater catchments and within peatlands typically reflect mobilisation of DOC that was produced rapidly under preceding warmer, drier and more aerobic conditions with rewetting and so flushing (Bonnett et al. 2006; Worrall et al. 2007; Clark et al. 2009). The initial high DOC concentrations observed in late 2011 may therefore reflect the relatively dry preceding summer of 2011 where precipitation was $8 \%$ lower than the LTA. In addition precipitation and river flows in the 4 months preceding the start of the study were below average so that the subsequent elevated concentrations of DOC are consistent with DOC flushing. By comparison, flows from June 2012 until late spring 2013 were relatively high with several storm events which imply that the potential for aerobic DOC production and accumulation for subsequent flushing would have been much reduced compared to the same period beginning from summer 2011 .

\section{Fluvial C fluxes as components of terrestrial C balances}

Net carbon balances that include fluvial components have been constructed for several disturbed and undisturbed peatlands in the temperate and boreal zones (Roulet et al. 2007; Nilsson et al. 2008; Worrall et al. 2009; Dinsmore et al. 2010; Koehler et al. 2010; Rowson et al. 2010). For such sites without considerable disturbance, these studies indicate sinks in the range of -20 to $-50 \mathrm{~g} \mathrm{C} \mathrm{m}^{-2} \mathrm{yr}^{-1}$ with fluvial fluxes equivalent to $34-46 \%$ of the net terrestrial $\mathrm{C}$ balances (gaseous exchange of $\mathrm{CO}_{2}$ and $\mathrm{CH}_{4}+$ rainfall DOC) with DOC fluxes alone equivalent to 14-37\%. Thus compared to DOC, fluvial $\mathrm{CO}_{2}$ fluxes and evasion have generally accounted for smaller fractions of the net terrestrial $\mathrm{C}$ balances of undisturbed temperate peatland systems, however this was not the case at our sites.

The component fluxes of the terrestrial $\mathrm{C}$ balance of the study sites given by Renou-Wilson et al. (2014) are shown in Fig. 5 for comparison with the fluvial $\mathrm{C}$ fluxes. This shows that biomass removals simulating the grazing intensity of the sites were considerable loss terms, without which the terrestrial balance (i.e. without fluvial fluxes incorporated) at Site A would have been a sink for c. $-30 \mathrm{~g}$ $\mathrm{C} \mathrm{m}^{-2} \mathrm{yr}^{-1}$, and so close to neutral when the fluvial $\mathrm{C}$ export is incorporated. Thus fluvial fluxes were equivalent to close to $100 \%$ of the net terrestrial balance at Site A when the biomass off take is excluded. Site B differed from 
Fig. 5 Net Ecosystem Carbon Budgets $\left(\mathrm{g} \mathrm{C} \mathrm{m}^{-2} \mathrm{yr}^{-1}\right)$ for Site A (2012 and 2013) and Site B (2012). Component terrestrial fluxes from Renou-Wilson et al. (2014); $R S$ Respiration, GPP Gross Primary Production; $\mathrm{CH}_{4}$ $L$ livestock enteric methane emission, Biomass simulated grazing off take, Rain DOC in precipitation, >eq. $\mathrm{CO}_{2}$ above saturation $\mathrm{CO}_{2}$. Standard errors are given in parentheses
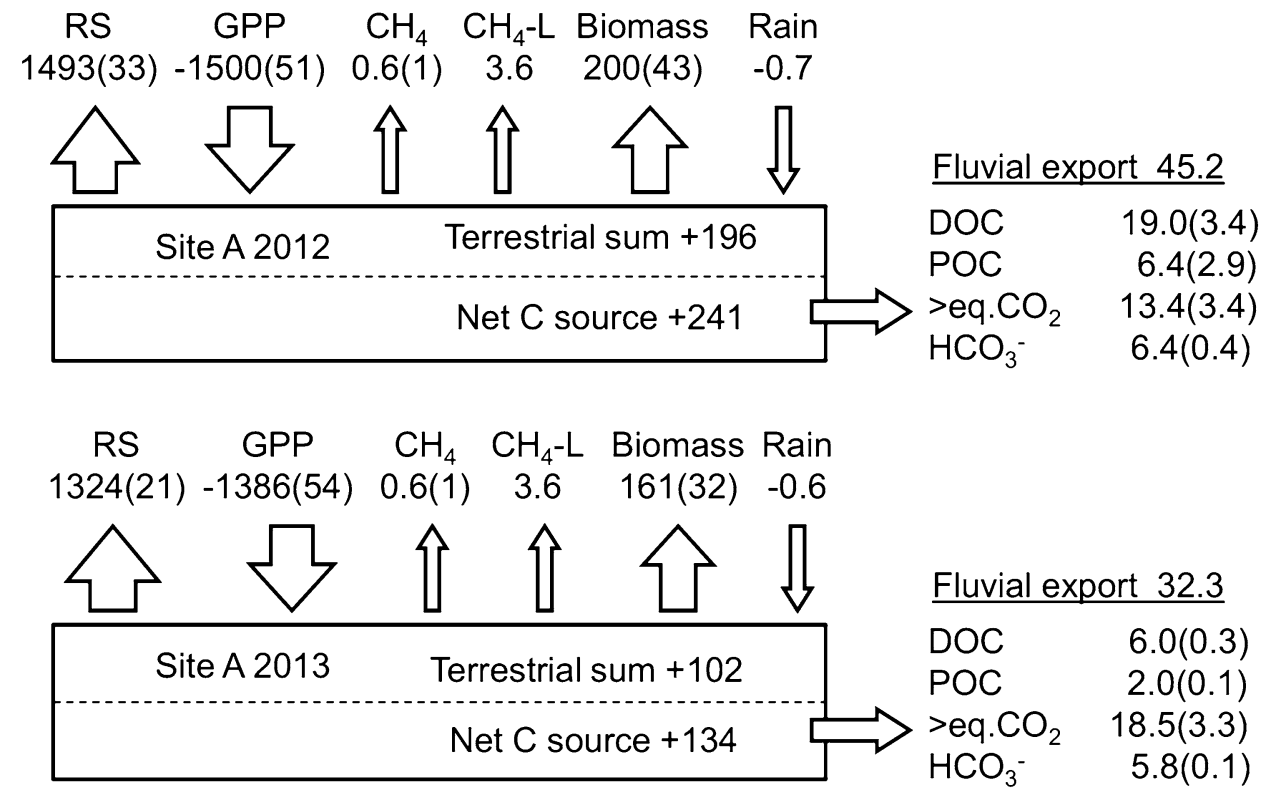

Site $\mathrm{A}$ in that terrestrial respiration exceeded primary production by a greater margin $\left(233 \mathrm{~g} \mathrm{C} \mathrm{m}^{-2} \mathrm{yr}^{-1}\right)$ and combined with higher fluvial $\mathrm{C}$ exports and biomass removal, the net ecosystem carbon balance was a source of $600 \mathrm{~g} \mathrm{C} \mathrm{m}^{-2} \mathrm{yr}^{-1}$. Biomass removal accounted for $60 \%$ of this balance, so that with or without this loss term Site B was a net $\mathrm{C}$ source before addition of fluvial exports (Fig. 5).

These sites clearly differ from the studies of peatlands previously referred to with respect to elevation, drainage modification and land use (vegetation and grazing intensity) while studies of pastures on drained organic soils have not incorporated fluvial fluxes. Couwenberg (2011) reviewed $\mathrm{C}$ emissions from several temperate drained organic soils under pasture in the range $410-760 \mathrm{~g} \mathrm{C} \mathrm{m}^{-2}$ $\mathrm{yr}^{-1}$. Biomass exports at our study sites were at the low end relative to these studies, but the absence of fluvial loss terms indicates that $\mathrm{C}$ emissions from the wetter, nutrient poor Site A were much lower than reported in the literature to date for similar sites. Indeed without the biomass removal terms the $\mathrm{C}$ status of Site $\mathrm{A}$ is close to neutral and analogous to the net $\mathrm{C}$ status of undisturbed upland temperate peatlands. The overall $\mathrm{C}$ balance at Site B was nevertheless within the range of these literature values. How representative the individual annual values for Site B are of the long term status of this site is unknown, however that precipitation and runoff were appreciably greater than long term averages in 2012 suggests that fluvial exports may be lower on average.

\section{DOC bioavailability}

The $\mathrm{C}$ dynamics of areas of high soil organic $\mathrm{C}$ are of interest for national and global $\mathrm{C}$ and greenhouse gas inventories, particularly for their potential to remineralise and return significant quantities of $\mathrm{C}$ to the atmosphere. Fluvial organic $\mathrm{C}$ fluxes are of interest in this respect as their magnitude and dynamics can reflect exports of $\mathrm{C}$ fixed decades to millennia earlier.

The gamma reactivity continuum model is among the most parsimonious of models applied to degradation time series. Furthermore, as there is no strict definition as to what distinguishes labile and refractory organic matter the associated gamma reactivity distributions present a useful means for comparing DOC reactivity. Koehler et al. (2012) used gamma model probability distributions to partition 
DOC among three reactivity classes: the fractions degraded at $\quad k>0.01 \mathrm{day}^{-1}, \quad 0.001<k<0.01 \mathrm{day}^{-1}, \quad$ and $k<0.001$ day $^{-1}$. Figure 6 shows the probability (reactivity) distributions of gamma model fits and associated timedependence of mean first-order decay coefficients for the mean model derived for this study, and for a range of $\mathrm{C}$ mass loss studies of freshwater dissolved organic matter (DOM) (headwater streams and boreal lakes). Also plotted are model fits to $\mathrm{C}$ mass loss timeseries of marine particulate organic matter, plankton exudates, and amino-acids from plankton exudates. Together these plots illustrate the spectrum of reactivities for natural organic matter, and by inference reactivity dependence on substrate chemical quality, as widely described for example by C:N (del Giorgio and Cole 1998; Hunt et al. 2000).

Figure 6 shows that more than $50 \%$ and up to $99 \%$ of the marine organic fractions, which consist of recently produced matter, were degraded at rates $>0.01$ day $^{-1}$. These are indicative of the reactivity of the most labile components likely to be present in natural freshwaters. Comparing the reactivity distributions of the stream and lake waters highlights the variable, but consistently very low abundance of such compounds relative to the bulk of much less reactive organic matter. For example, matter with reactivities $>0.01 \mathrm{~d}^{-1}$ account for only $0.8-20 \%$ of dissolved organic matter in these stream and lake samples (Fig. 6a, c) which is degraded over the first 10 days (Fig. 6b, d). Degradation rates $<0.01$ day $^{-1}$ for these samples accounted for variable fractions of initial DOM, but notably the reactivity distributions of the mean model fit to our data, and that of a Scottish moorland headwater stream sampled at low flow (Stutter et al. 2013) are very similar, and much less reactive relative to other freshwater samples. Wide disparity between the reactivity distributions of DOM samples taken at high and low flow from the Scottish moorland highlight the role of seasonality and hydrology as controls on the composition and quality of DOM exports (Ågren et al. 2008; Stutter et al. 2013). In
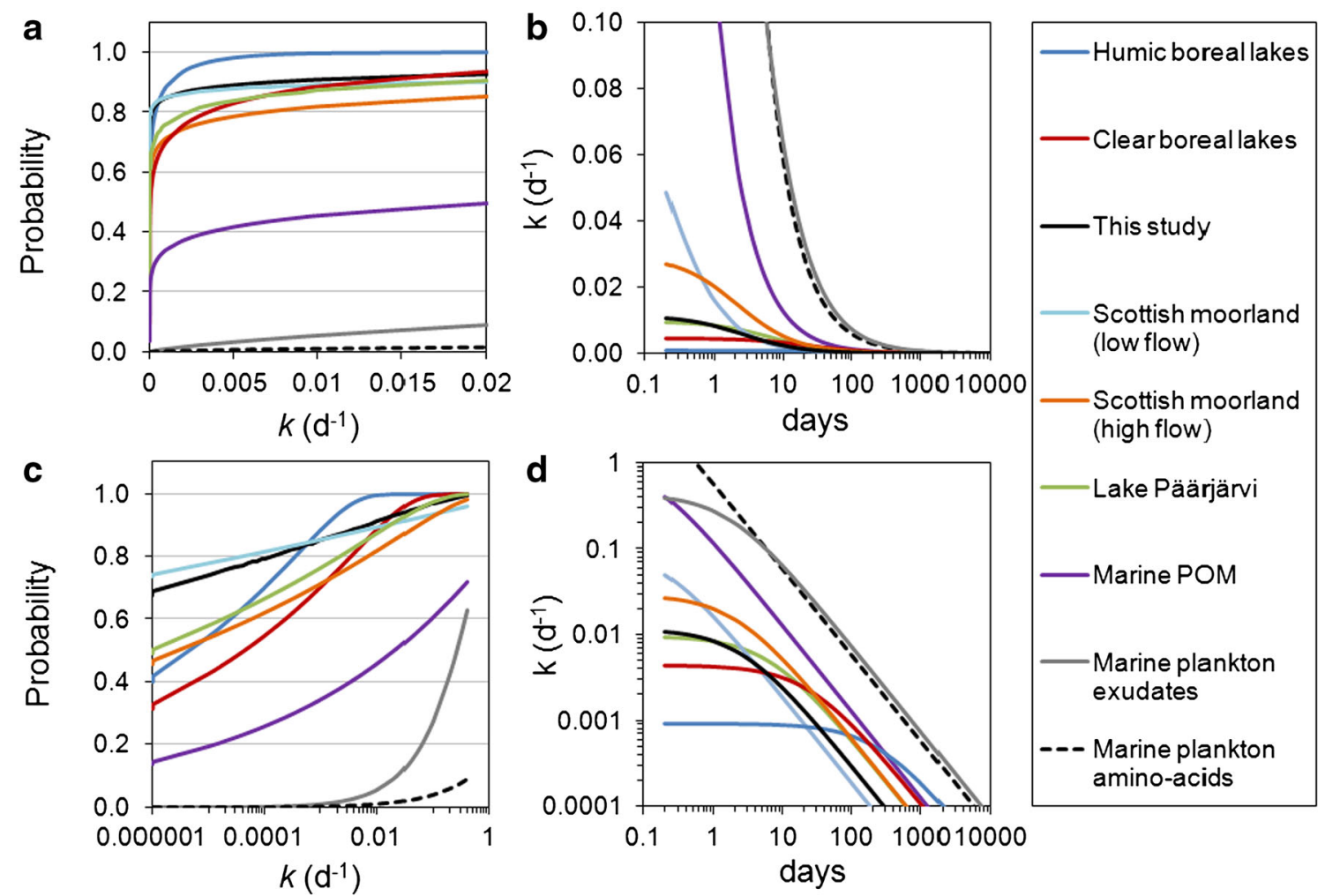
(high flow)

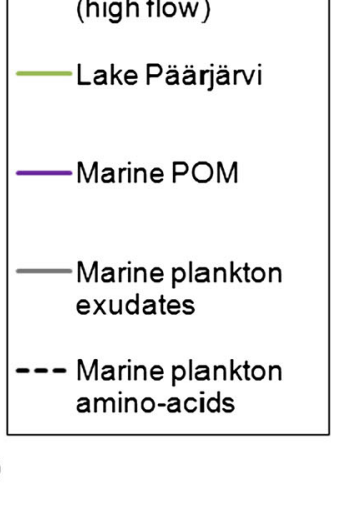

Fig. 6 Initial reactivity distributions (a, c) and mean first-order decay coefficients over time $(\mathbf{b}, \mathbf{d})$ for gamma model fits to literature data sources. 'Humic' and 'Clear boreal lakes' are means of $\alpha, v$ fitted by Koehler et al. (2012) to dissolved organic matter (DOM) degradation (humic: $\alpha, v=251,0.23$; clear: $\alpha, v=25,0.11$ ); 'This study' represents the average $\alpha, v$ of samples $(\alpha, v=2.44,0.03)$, 'Scottish moorland' are fits to degradation data of DOM from a Scottish peaty moorland stream sampled at high and low flow (Stutter et al. 2013) (high flow $\alpha, v=2.1,0.06$; low flow $\alpha, v=0.18,0.02$ ); 'Lake Päärjärvi' is fit to DOM degradation by Vähätalo et al. (2010) $(\alpha$,

$v=6.43,0.06$ ); 'Marine POM' is fit by Boudreau and Ruddick (1991) $(\alpha, v=0.113,0.125)$ to oxic degradation data of marine spring bloom plankton (mainly diatoms) of Westrich and Berner (1984); 'Marine plankton exudates' and 'Marine plankton amino-acids' are, firstly, the fit to degradation data for of exudates $(<0.7 \mu \mathrm{m})$ from concentrated marine plankton $(>50 \mu \mathrm{m}$; largely diatoms $)(\alpha$, $v=1.67,0.73)$, and secondly, the fit to degradation of amino-acids $(\alpha, v=0.03,0.58)$ extracted from these exudates as given by Davis and Benner (2007) 
this respect the reactivity distributions of DOM from our sites were variable but without clear relationships with instantaneous or antecedent flows. A variety of factors will affect the reactivity of DOM, including microbial utilisation and photodegradation prior to sample acquisition, hydrological impacts on DOM soil profile origin, and fresh DOM inputs from autochthonous primary production. Seasonal studies of DOM degradation over event hydrographs and for soil DOM extracts under varying soil, soil moisture and land use may provide a more robust understanding of the key soil C sources involved, and so their relative fate and ecosystem impact.

DOC mineralisation rates and quantities were determined at $20{ }^{\circ} \mathrm{C}$ with a nutrient excess and so are indicative of the potential for remineralisation rather than being realistic environmentally; temperatures of drainage waters in this study only briefly approached $20^{\circ} \mathrm{C}$ and inorganic nutrients are expected to be low given the low input management regimes at these sites. However, in Ireland even if the drainage water is of low nutrient status there is a strong possibility that it will encounter more enriched waters downstream. While these experimental factors would elevate mineralisation relative to the natural environment, samples were incubated in the dark so excluding the potential for photo-oxidation and photo-cleavage, which can be appreciable, and in the latter case can increase organic matter lability considerably (Graneli et al. 1996; Bano et al. 1998; Bertilsson and Tranvik 2000).

The role of photoreactions for DOC bleaching, photooxidative production of DIC from DOC, and for photolytic production of more labile lower molecular weight DOC from larger, more refractory DOC have been studied since the late 1970s. With respect to photo-oxidation, Graneli et al. (1996) found that rates of photo-oxidation in the surface waters of humic boreal lakes were similar to, or exceeded rates of community respiration implying that abiotic processes can be as important as heterotrophic metabolism for DOC remineralisation, while photolytic production of labile compounds from the DOC of a freshwater wetland elevated bacterial utilisation of DOC by up to $300 \%$ (Bano et al. 1998).

Obernosterer and Benner (2004) identified fractions of wetland DOC that were susceptible to both photo-mineralisation and microbial mineralisation, as well as fractions individually susceptible to either heterotrophic mineralisation or photo-mineralisation, and photo-mediated increases to labile fractions available for heterotrophic metabolism. More recently Moody et al. (2013) found that degradation of high DOC samples (c. $50 \mathrm{mg} \mathrm{l}^{-1}$ ) from English peatland streams incubated at ambient light conditions was $73 \%$ on average over 10 days, whereas for samples kept in the dark the average was $45 \%$. These fractions are both considerably greater than determined for samples from our sites which were incubated in the dark (3-6\% loss over 10 days). Freezing can cause abiotic precipitation of dissolved organic matter (Giesy and Briese 1978) so that the extent to which the high DOC losses documented by Moody et al. (2013) may have been artefacts of sample preservation by freezing with the subsequent post-thaw filtration employed is uncertain. Nevertheless, Fellman et al. (2008) describe post thaw declines in DOC concentration of 10-30\% for initial sample concentrations of $10-40 \mathrm{mg} \mathrm{l}^{-1}$; if such losses are appropriate for UK stream waters, such as those examined by Moody et al. (2013), then degradation rates derived herein still remain considerably lower. Conversely however, Peacock et al. (2015) found that DOC concentration disparities between freeze-thawed and unfrozen samples were generally within the range of analytical precision.

As our approach did not incorporate assessments of the propensity for photo-oxidation of the organic $\mathrm{C}$ exports, or for generation of labile DOC fractions via photolysis, the estimated quantities of DOC remineralised probably underestimate the situation in the environment despite the elevated temperature and nutrients employed in the incubations. Due to differences in the chemical characteristics of DOC between studies, and between samples taken during different seasons or under different hydrological or water chemistry conditions that can affect DOC reactivity (Wickland et al. 2007, 2012; Wilson and Xenopoulos 2009; Hunt et al. 2000) it is difficult to assess the extent to which photo-mineralisation and photocleavage would have elevated the quantities of organic $\mathrm{C}$ mineralised at our sites. This area requires further study within the Irish ecoregion, however the annual seasonality of runoff in temperate maritime regions means that the majority of the DOC export occurs during the winter period of declining solar irradiance when water residence times are also shortest. This contrasts with many north temperature boreal regions where peak DOC export at spring freshet precedes the summer period of peak irradiance (e.g. Ågren et al. 2008).

Several studies have examined respiration of soilderived dissolved organic matter by similar approaches. Bowen et al. (2009) determined proportions of soil-derived DOC mineralised from two contrasting forested Scottish peatlands close to the minimum and maximum proportions for our sites at 4.7 and $38.5 \%$ over 70 days and at $20{ }^{\circ} \mathrm{C}$, but with proportions for agricultural soils in the range 11-29\%. Similarly Kalbitz et al. (2003) determined mineralisation of 17-32\% soil-derived DOC over 90 days at $20{ }^{\circ} \mathrm{C}$ for agricultural soils but only 4-9 \% for fen peats which is similar to samples from Site B.

We employed remineralisation rates as proxies for microbial DOC degradation (bacterial utilisation; BU) yet overall DOC degradation encompasses both remineralisation losses (bacterial respiration; BR) and $\mathrm{C}$ incorporated 
as microbial biomass (bacterial production; BP) (del Giorgio and Cole 1998). DOC losses inferred from BOD will therefore underestimate degradation if BP occurs. Further caveats are the assumption of an $R Q=1$ over the period of incubation, as RQ's could potentially rise from $<1$ to $>1$ with transition from utilisation of labile to more refractory substrates (del Giorgio and Cole 1998; Berggren et al. 2012).

The proportion of BU as BP (termed bacterial growth efficiency, BGE) varies widely across aquatic systems but is typically between 1 and $50 \%$, and like RQ's depends largely on substrate quality but also the form and availability of inorganic nutrients, and consequently BGE tends to increase with aquatic primary productivity (del Giorgio and Cole 1998). The changing reactivity of labile $C$ during degradation implies declining substrate quality which would be expected to result in declining BGE (Berggren et al. 2007, 2009). Consequently potential inaccuracies due to assumed RQ and unquantified BP will operate in opposing directions, but to what extent these annul each other is unclear. For aged unproductive Swedish humic lake water BGE did not exceed $10 \%$ (Eiler et al. 2003) and this value may be appropriate for the more refractory DOC in this study. Similarly BGE at $20{ }^{\circ} \mathrm{C}$ for DOC derived from a mixed Swedish forest-mire declined from 16 to $35 \%$ initially to c. $10 \%$ at 70 days (Berggren et al. 2009). Bowen et al. (2009) determined both mineralisation and total DOC loss for soil DOC at $20^{\circ} \mathrm{C}$ over 70 days from two forested peatlands in Scotland; a drained peatland and a blanket peatland. Mineralisation accounted for the total DOC mass loss of DOC for the drained site, implying maintenance respiration and no overall $\mathrm{BP}$, but was equivalent to $88 \%$ of the DOC mass loss for the blanket peatland so that BGE for this site was $12 \%$.

These studies suggest that BP over the early stages of our incubations (20 days) may be c. $20 \%$ of the total DOC mass loss, and for the latter incubation period (20-90 days) c. $10 \%$. Based on the average reactivity continuum model parameters ( $\alpha$ and $v$ ) for each site, DOC mineralisation accounted for 6.3 and $3.7 \%$ of initial DOC by day 20 for Sites A and B respectively. Assuming these quantities accounted for $80 \%$ DOC mass loss, the losses would be equivalent to 7.8 and $4.6 \%$ of initial DOC respectively at day 20. Applying the same approach for the period 20-90 days, and assuming mineralisation accounted for $90 \%$ of total mass loss over this period, the total DOC loss at 90 days would be equivalent to 11.9 and $7.5 \%$ initial DOC on average, compared to 9.9 and $6.3 \%$ initial DOC for mineralisation alone. These differences suggest a relatively minor underestimation of DOC loss during downstream transport due to BP so that comparisons with DOC degradation studies, as given in Fig. 6, are not precluded.

\section{Conclusions}

Fluvial DOC fluxes determined close to source from Irish pastures on drained organic soils were comparable to those reported for temperate peatlands, and DIC fluxes were also similar when prior $\mathrm{CO}_{2}$ evasion from headwaters is incorporated. The impact of monitoring scale on total DIC flux due to prior $\mathrm{CO}_{2}$ evasion were less pronounced for the site with extensive underlying carboniferous geology compared to the site on non-carboniferous terrain, presumably due to reduced air-water $\mathrm{CO}_{2}$ gradients due to export of soil respiratory $\mathrm{CO}_{2}$ in the form of bicarbonate via weathering dissolution. This study highlights that monitoring at soil-water interfaces can aid capture of total landscape fluvial fluxes by precluding the need for incorporation of estimates of prior $\mathrm{C}$ losses for monitoring at wider catchment scales. However, rapid runoff responses at field scales can require high resolution flow proportional, and hydrograph sampling to constrain uncertainty of flux estimates. By comparison to most studies of pastures on organic soils the terrestrial carbon balance of the low nutrient, relatively wet site was a small net $\mathrm{C}$ source, with fluvial fluxes almost equivalent to the balance between terrestrial GPP and R. In contrast the $\mathrm{C}$ balance of the nutrient rich site was similar to other European pastures situated on drained peat, operating as a considerable net $\mathrm{C}$ source with the fluvial flux equivalent to $30 \%$ of the balance between GPP minus R. The labile fractions of DOC were low yet variable, but within the ranges reported for similar studies, indicating small fractions $(5-10 \%)$ remineralised over the typical time course of downstream transit of days to weeks, unless features that extend water residence such as lakes are encountered. The potential for photo-enhanced lability remains to be tested however, with literature studies suggesting greater fractions may be mineralised under environmental conditions. The propensity for organic $\mathrm{C}$ exports to drive bacterial production also remains to be tested and may be of importance with respect to influences on aquatic ecosystem functioning.

Acknowledgments We thank Bill Clarke (AFBI), Mark Scott (Rivers Agency Northern Ireland), and Rachel Cassidy (AFBI) for helpful discussions on discharge instrumentation and non-linear regression, and reviewers for helpful comments which improved the manuscript. This work was funded by the Irish Environmental Protection Agency Climate Change Research Programme 2006-2013, as part of the Strategy for Science, Technology and Innovation Programme and the National Development Plan 2007-2013.

Open Access This article is distributed under the terms of the Creative Commons Attribution 4.0 International License (http://creative commons.org/licenses/by/4.0/), which permits unrestricted use, distribution, and reproduction in any medium, provided you give appropriate credit to the original author(s) and the source, provide a link to the Creative Commons license, and indicate if changes were made. 


\section{References}

Ågren A, Berggren M, Laudon H, Jansson M (2008) Terrestrial export of highly bioavailable carbon from small boreal catchments in spring floods. Freshw Biol 53:964-972

Aitkenhead-Peterson JA, Alexander JE, Clair TA (2005) Dissolved organic carbon and dissolved organic nitrogen export from forested watersheds in Nova Scotia: identifying controlling factors. Global Biogeochem Cycles. doi:10.1029/2004GB002438

Aris R (1989) Reactions in continuous mixtures. AIChE J 35(4):539-548

Aufdenkampe AK et al (2011) Riverine coupling of biogeochemical cycles between land, oceans, and atmosphere. Front Ecol Environ 9:53-60. doi:10.1890/100014

Bano N, Moran MA, Hodson RE (1998) Photochemical formation of labile organic matter from two components of dissolved organic carbon in a freshwater wetland. Aquat Microb Ecol 16:95-102

Bates D, Maechler M, Bolker B (2013) lme4: Linear mixed-effects models using S4 classes. R package version 0.999999-2. http:// www.CRAN.R-project.org/package $=1 \mathrm{me} 4$

Battin TJ, Luyssaert S, Kaplan LA, Aufdenkampe AK, Richter A, Tranvik LJ (2009) The boundless carbon cycle. Nat Geosci 2:598-600

Beaulieu E, Godderis Y, Donnadieu Y, Labat D, Roelandt C (2012) High sensitivity of the continental-weathering carbon dioxide sink to future climate change. Nature Clim Change 2:346-349

Berggren M, Laudon H, Jansson M (2007) Landscape regulation of bacterial growth efficiency in boreal freshwaters. Global Biogeochem Cycles 21:GB4002. doi: 10.1029/2006gb002844

Berggren M, Laudon H, Jansson M (2009) Aging of allochthonous organic carbon regulates bacterial production in unproductive boreal lakes. Limnol Oceanogr 54(4):1333-1342

Berggren M, Lapierre J-F, del Giorgio PA (2012) Magnitude and regulation of bacterioplankton respiratory quotient across freshwater environmental gradients. ISME J 6(5):984-993

Bertilsson S, Tranvik L (2000) Photochemical transformation of dissolved organic matter in lakes. Limnol Oceanogr 45:753-762

Billett MF, Palmer SM, Hope D, Deacon C, Storeton-West R, Hargreaves KJ, Flechard C, Fowler D (2004) Linking landatmosphere-stream carbon fluxes in a lowland peatland system. Global Biogeochem Cycles 18:GB1024

Birge EA, Juday C (1927) The organic content of the water of small lakes. Proc Amer Phil Soc 666:357-372

Bishop K, Buffam I, Erlandsson M, Fölster J, Laudon H, Seibert J, Temnerud J (2008) Aqua Incognita: the unknown headwaters. Hydrol Process 22:1239-1242

Bonnett SAF, Ostle N, Freeman C (2006) Seasonal variations in decomposition processes in a valley-bottom riparian peatland. Sci Total Environ 370:561-573

Boudreau BP, Ruddick BR (1991) On a reactive continuum representation of organic matter diagenesis. Am J Sci 291:507-538

Bowen S, Gregorich E, Hopkins D (2009) Biochemical properties and biodegradation of dissolved organic matter from soils. Biol Fertil Soil 45:733-742. doi:10.1007/s00374-009-0387-6

Butman D, Raymond PA (2011) Significant efflux of carbon dioxide from streams and rivers in the United States. Nat Geosci 4:839-842

Canadell JG, Le Quéré C, Raupach MR, Field CB et al (2007) Contributions to accelerating atmospheric $\mathrm{CO}_{2}$ growth from economic activity, carbon intensity, and efficiency of natural sinks. P Nat Acad Sci USA 104:18866-18870. doi: 10.1073/ pnas.0702737104

Cannell MGR, Milne R, Hargreaves KJ, Brown TAW et al (1999) National inventories of terrestrial carbon sources and sinks: the UK experience. Clim Change 42:505-530
Cantrell KJ, Serkiz SM, Perdue EM (1990) Evaluation of acid neutralizing capacity data for solutions containing natural organic acids. Geochim Cosmochim Acta 54:1247-1254. doi:10.1016/0016-7037(90)90150-J

Clark JM, Ashley D, Wagner M, Chapman PJ, Lane SN, Evans CD, Heathwaite AL (2009) Increased temperature sensitivity of net DOC production from ombrotrophic peat due to water table draw-down. Glob Change Biol 15:794-807. doi:10.1111/ j.1365-2486.2008.01683.x

Cole JJ, Caraco NF, Kling GW, Kratz TK (1994) Carbon-dioxide supersaturation in the surface waters of lakes. Science 265:1568-1570

Cole J et al (2007) Plumbing the global carbon cycle: integrating inland waters into the terrestrial carbon budget. Ecosystems 10:172-185. doi:10.1007/s10021-006-9013-8

Couwenberg J (2011) Greenhouse gas emissions from managed peat soils: is the IPCC reporting guidance realistic? Mire Peat 8(2): $1-10$

Davis J, Benner R (2007) Quantitative estimates of labile and semilabile dissolved organic carbon in the western Arctic Ocean: a molecular approach. Limnol Oceanogr 52:2434-2444

Dawson JJC, Smith P (2007) Carbon losses from soil and its consequences for land-use management. Sci Total Environ 382(2-3):165-190

Dawson JJC, Billett MF, Hope D, Palmer SM, Deacon CM (2004) Sources and sinks of aquatic carbon in a peatland stream continuum. Biogeochemistry 70:71-92

Dawson JJC, Soulsby C, Tetzlaff D, Hrachowitz M, Dunn SM, Malcolm IA (2008) Influence of hydrology and seasonality on DOC exports from three contrasting upland catchments. Biogeochemistry 90:93-113

Dean WE (1974) Determination of carbonate and organic matter in calcareous sediments and sedimentary rocks by loss on ignition; comparison with other methods. J Sediment Res 44(1):242-248

del Giorgio PA, Cole JJ (1998) Bacterial growth efficiency in natural aquatic systems. Annu Rev Ecol Syst 29:503-541

Dinsmore KJ, Billett MF, Skiba UM, Rees RM, Drewer J, Helfter C (2010) Role of the aquatic pathway in the carbon and greenhouse gas budgets of a peatland catchment. Glob Change Biol 16:2750-2762. doi:10.1111/j.1365-2486.2009.02119.x

Eiler A, Langenheder S, Bertilsson S, Tranvik LJ (2003) Heterotrophic Bacterial Growth Efficiency and Community Structure at Different Natural Organic Carbon Concentrations. Appl Environ Microbiol 69:3701-3709. doi:10.1128/aem.69.7.3701-3709. 2003

EPA (2008) State of the Environment Report. Environmental Protection Agency, Ireland

EPA (2014) HydroNet http://www.hydronet.epa.ie. Accessed November 2014

FAO (1998) World Reference Base for Soil Resources, World Soil Resources Report no. 84, FAO Rome

Fasching C, Behounek B, Singer GA, Battin TJ (2014) Microbial degradation of terrigenous dissolved organic matter and potential consequences for carbon cycling in brown water streams. Sci Rep 4:4981. doi:10.1038/srep04981

Fellman JB, D'Amore DV, Hood E (2008) An evaluation of freezing as a preservation technique for analyzing dissolved organic $\mathrm{C}, \mathrm{N}$ and $\mathrm{P}$ in surface water samples. Sci Total Environ 392:305-312 doi: http://www.dx.doi.org/10.1016/j.scitotenv.2007.11.027

Gibson HS, Worrall F, Burt TP, Adamson JK (2009) DOC budgets of drained peat catchments: implications for DOC production in peat soils. Hydrol Process 23:1901-1911

Giesy JP, Briese LA (1978) Particulate formation due to freezing humic waters. Water Resour Res 14:542-544. doi:10.1029/ WR014i003p00542 
Perdue EM, Gjessing, ET (1990) Organic acids in aquatic ecosystems: Report on the Dahlem workshop on organic acids in aquatic ecosystems. Chichester, John Wiley \& Sons. ISBN 0471926310

Graneli W, Lindell M, Tranvik L (1996) Photo-oxidative production of dissolved inorganic carbon in lakes of different humic content. Limnol Oceanogr 41:698-706

Grant DM, Dawson BD (1997) ISCO open channel flow measurement handbook. ISCO Inc, Lincoln

Hedin LO, Likens GE, Postek KM, Driscoll CT (1990) A field experiment to test wether organic acids buffer acid deposition. Nature 345(6248):798-800

Hope D, Billett MF, Cresser MS (1994) A review of the export of carbon in river water-fluxes and processes. Environ Pollut 84:301-324

Hope D, Billett MF, Cresser MS (1997) Exports of organic carbon in two river systems in NE Scotland. J Hydrol 193:61-82. doi:10. 1016/S0022-1694(96)03150-2

Hope D, Palmer SM, Billett MF, Dawson JJC (2001) Carbon dioxide and methane evasion from a temperate peatland stream. Limnol Oceanogr 46:847-857

Hunt AP, Parry JD, Hamilton-Taylor J (2000) Further evidence of elemental composition as an indicator of bioavailability of humic substances to bacteria. Limnol Oceanogr 41:23-241

Hunt CW, Salisbury JE, Vandemark D (2011) Contribution of noncarbonate anions to total alkalinity and overestimation of $\mathrm{pCO}_{2}$ in New England and New Brunswick rivers. Biogeosciences 8:3069-3076. doi:10.5194/bg-8-3069-2011

IPCC (2006) IPCC guidelines for national greenhouse gas inventories. Prepared by National Greenhouse Gas Inventories Programme, IGES, Japan

Joosten H, Tapio-Biström M-L, Tol S (Eds) (2012) Peatlandsguidance for climate change mitigation through conservation, rehabilitation and sustainable use. 2nd Ed. Mitigation of climate change in agriculture series 5. FAO

Kalbitz K, Schmerwitz J, Schwesig D, Matzner E (2003) Biodegradation of soil-derived dissolved organic matter as related to its properties. Geoderma 113:273-291

Kindler R, JaN Siemens, Kaiser K et al (2011) Dissolved carbon leaching from soil is a crucial component of the net ecosystem carbon balance. Glob Change Biol 17:1167-1185

Koehler A-K, Sottocornola M, Kiely G (2010) How strong is the current carbon sequestration of an Atlantic blanket bog?. Glob Change Biol doi:10.1111/j.1365-2486.2010.02180.x

Koehler B, Von Wachenfeldt E, Kothawala D, Tranvik LJ (2012) Reactivity continuum of dissolved organic carbon decomposition in lake water. J Geophys Res: Biogeosci 117:G01024. doi: 10. 1029/2011JG001793

Kortelainen P (1993) Contribution of organic acids to the acidity of Finnish lakes. Publications of the Water and Environment Research Institute. National Board of Waters and the Environment, Helsinki

Littlewood IG (1992) Estimating constituent loads in rivers: a review. Institute of Hydrology, UK, Wallingford

Maberly SC, Barker PA, Stott AW, De Ville MM (2013) Catchment productivity controls $\mathrm{CO}_{2}$ emissions from lakes. Nature Clim Change 3:391-394

Marín-Spiotta E, Gruley KE, Crawford J, Atkinson EE et al (2014) Paradigm shifts in soil organic matter research affect interpretations of aquatic carbon cycling: transcending disciplinary and ecosystem boundaries. Biogeochemistry 117:279-297. doi:10. 1007/s10533-013-9949-7

Mills G (2000) Modelling the water budget of Ireland- evapotranspiration and soil moisture. Irish Geogr 33:99-116

Moody CS, Worrall F, Evans CD, Jones TG (2013) The rate of loss of dissolved organic carbon (DOC) through a catchment. J Hydrol 492:139-150. doi:10.1016/j.jhydrol.2013.03.016
Nilsson M et al (2008) Contemporary carbon accumulation in a boreal oligotrophic minerogenic mire-a significant sink after accounting for all C-fluxes. Glob Change Biol 14:2317-2332. doi:10. 1111/j.1365-2486.2008.01654.x

Obernosterer I, Benner R (2004) Competition between biological and photochemical processes in the mineralisation of dissolved organic carbon. Limnol Oceanogr 49(1):117-124

Öquist MG, Wallin M, Seibert J, Bishop K, Laudon H (2009) Dissolved inorganic carbon export across the soil/stream interface and its fate in a boreal headwater stream. Environ Sci Technol 43:7364-7369. doi:10.1021/es900416h

Peacock M, Freeman C, Gauci V, Lebron I, Evans CD (2015) Investigations of freezing and cold storage for the analysis of peatland dissolved organic carbon (DOC) and absorbance properties. Environ Sci: Process Impacts 17:1290-1301

Prairie YT (2008) Carbocentric limnology: looking back, looking forward. Can J Fish Aquat Sci 65:543-548

Rantakari M, Kortelainen P (2008) Controls of organic and inorganic carbon in randomly selected Boreal lakes in varied catchments. Biogeochemistry 91(2-3):151-162

Raymond PA, Hartmann J, Lauerwald R, Sobek S et al (2013) Global carbon dioxide emissions from inland waters. Nature 503:355-359. doi:10.1038/nature 12760

Renou-Wilson F, Barry C, Müller C, Wilson D (2014) The impacts of drainage, nutrient status and management practice on the full carbon balance of grasslands on organic soils in a maritime temperate zone. Biogeosciences 11:4361-4379. doi:10.5194/bg11-4361-2014

Reuschenbach P, Pagga U, Strotmann U (2003) A critical comparison of respirometric biodegradation test based on OECD 301 and related test methods. Wat Res 37:1571-1582

Roila T, Kortelainen P, David MB, Mäkinen I (1994) Effect of organic anions on acid neutralizing capacity in surface waters. Environ Internat 20:369-372. doi:10.1016/0160-4120(94) 90122-8

Roulet NT, Lafleur PM, Richard PJH, Moore TR, Humphreys ER, Bubier J (2007) Contemporary carbon balance and late Holocene carbon accumulation in a northern peatland. Glob Change Biol 13:397-411. doi:10.1111/j.1365-2486.2006.01292.x

Rowson JG, Gibson HS, Worrall F, Ostle N, Burt TP, Adamson JK (2010) The complete carbon budget of a drained peat catchment. Soil Use Manag 26:261-273. doi:10.1111/j.1475-2743.2010. 00274.x

Royer TV, David MB (2005) Export of dissolved organic carbon from agricultural streams in Illinois USA. Aquat Sci 67:465-471. doi:10.1007/s00027-005-0781-6

Smith P, Powlson D, Glendining M, Smith JO (1997) Potential for carbon sequestration in European soils: preliminary estimates for five scenarios using results from long-term experiments. Glob Change Biol 3:67-79. doi:10.1046/j.1365-2486.1997.00055.x

Søndergaard M, Middleboe M (1995) A cross-system analysis of labile dissolved organic carbon. Mar Ecol Prog Sers 118:283-294

Stallard RF (1998) Terrestrial sedimentation and the carbon cycle: coupling weathering and erosion to carbon burial. Global Biogeochem Cycles 12(2):231-257

Stumm W, Morgan JJ (1996) Aquatic Chemistry, Chemical Equilibria and Rates in Natural Waters. 3rd Edn. John Wiley \& Sons, Inc,

Stutter MI, Richards S, Dawson JJC (2013) Biodegradability of natural dissolved organic matter collected from a UK moorland stream. Water Res. doi: 10.1016/j.watres.2012.11.035

Telmer K, Veizer J (1999) Carbon fluxes, $\mathrm{pCO}_{2}$ and substrate weathering in a large northern river basin, Canada: carbon isotope perspectives. Chem Geol 159:61-86

Thompson JJD, Doody DG, Flynn R, Watson CJ (2012) Dynamics of critical source areas: does connectivity explain chemistry? Sci 
Total Environ 435-436:499-508. doi:10.1016/j.scitotenv.2012. 06.104

Thornwaite CW, Mather JR (1955) The water balance. Publ Climatol Lab Climatol Drsel Inst Technol 8(8):1-104

Tomlinson RW (2005) Soil carbon stocks and changes in the Republic of Ireland. J Env Man 76:77-93

Tranvik LJ, Downing JA, Cotner JB et al (2009) Lakes and reservoirs as regulators of carbon cycling and climate. Limnol Oceanogr 54(6:2):2298-2314

Vähätalo A, Aarnos H, Mäntyniemi S (2010) Biodegradability continuum and biodegradation kinetics of natural organic matter described by the beta distribution. Biogeochemistry 100:227-240

Wallin MB, Grabs T, Buffam I, Laudon H, Ågren A, Öquist MG, Bishop K (2013) Evasion of $\mathrm{CO}_{2}$ from streams - The dominant component of the carbon export through the aquatic conduit in a boreal landscape. Glob Change Biol 19:785-797. doi:10.1111/ gcb. 12083

Walling DE, Webb BW (1985) Estimating the discharge of contaminants to coastal waters by rivers-some cautionary comments. Mar Poll Bul 16:488-492

Westrich JT, Berner RA (1984) The role of sedimentary organic matter in bacterial sulphate reduction: the $G$ model tested. Limnol Oceanogr 29:236-249

Whitfield CJ, Aherne J, Baulch HM (2011) Controls on greenhouse gas concentrations in polymictic headwater lakes in Ireland. Sci
Total Environ 410-411:217-225. doi:10.1016/j.scitotenv.2011. 09.045

Wickland KP, Neff JC, Aiken GR (2007) Dissolved organic carbon in Alaskan Boreal Forest: sources, chemical characteristics, and biodegradability. Ecosystems 10:1323-1340

Wickland KP, Aiken GR, Butler K, Dornblaser MM, Spencer RGM, Striegl RG (2012) Biodegradability of dissolved organic carbon in the Yukon River and its tributaries: seasonality and importance of inorganic nitrogen. Global Biogeochem Cycles 26:GB0E03

Willey JD, Kieber RJ, Eyman MS, Avery GB (2000) Rainwater dissolved organic carbon: concentrations and global flux. Global Biogeochem Cycles 14(1):139-148

Wilson HF, Xenopoulos MA (2009) Effects of agricultural land use on the composition of fluvial dissolved organic matter. Nat Geosci 2:37-41

Worrall F, Gibson HS, Burt TP (2007) Modelling the impact of drainage and drain-blocking on dissolved organic carbon release from peatlands. J Hydrol 338:15-27. doi:10.1016/j.jhydrol.2007. 02.016

Worrall F, Burt TP, Rowson JG, Warburton J, Adamson JK (2009) The multi-annual carbon budget of a peat-covered catchment. Sci Total Environ 407:4084-4094

Xu X, Liu W, Zhang C, Kiely G (2011) Estimation of soil organic carbon stock and its spatial distribution in the Republic of Ireland. Soil Use Manag 27:156-162 